\title{
Marine cage culture and the environment: effects on water quality and primary production
}

\author{
Carol Price $^{1, *}$, Kenneth D. Black ${ }^{2}$, Barry T. Hargrave ${ }^{3}$, James A. Morris Jr. ${ }^{1}$ \\ ${ }^{1}$ Center for Coastal Fisheries and Habitat Research, National Centers for Coastal Ocean Science, \\ National Ocean Service, NOAA, 101 Pivers Island Rd., Beaufort, North Carolina 28516, USA \\ ${ }^{2}$ SAMS, Scottish Marine Institute, Oban, Argyll, PA37 1QA, UK \\ ${ }^{3} 561$ Balmy Beach Road, Owen Sound, Ontario N4K 5N4, Canada
}

\begin{abstract}
Increasing human population and reliance on aquaculture for seafood will lead to expansion of the industry in the open ocean. To guide environmentally sustainable expansion, coastal stakeholders require tools to evaluate the risks that marine aquaculture poses and to craft science-based policies and practices which safeguard marine ecosystems. We summarized current knowledge regarding dissolved nutrient loading from marine fish farms around the world, direct impacts on water quality and secondary impacts on primary production, including formation of harmful algal blooms. We found that modern operating conditions have minimized impacts of individual fish farms on marine water quality. Effects on dissolved oxygen and turbidity are largely eliminated through better management. Nutrient enrichment of the near-field water column is not detectable beyond $100 \mathrm{~m}$ of a farm when formulated feeds are used, and feed waste is minimized. We highlight the role of siting fish farms in deep waters with sufficient current to disperse nutrients and prevent water quality impacts. We extensively discuss the potential for advances in integrated multi-trophic aquaculture (IMTA) to assimilate waste nutrients. Although modern farm management practices have decreased environmental effects of marine fish farms, we conclude that questions remain about the additive impacts of discharge from multiple farms potentially leading to increased primary production and eutrophication. Research results on secondary effects upon primary production are highly variable. In some locations, nutrient loading has little or no trophic impact, while at others there is evidence that nutrients are assimilated by primary producers. Research on far-field and regional processes, especially in intensively farmed areas and over longer time scales, will refine understanding of the full ecological role of fish farms in marine environments.
\end{abstract}

KEY WORDS: Marine aquaculture - Environmental impacts - Dissolved nutrients - Oxygen · Nitrate $\cdot$ Phosphorus $\cdot$ Harmful algal blooms $\cdot$ Mitigation strategies

\section{INTRODUCTION}

The marine finfish aquaculture industry is expanding as demand for seafood rises but cannot be met by wild catch fisheries (Halwart et al. 2007). Technological innovations have made the aquaculture production of seafood possible in coastal and open ocean areas and these industries are now reliably providing in-

${ }^{*}$ Corresponding author: carol.price@noaa.gov creasing amounts of marine protein. Marine aquaculture production has reached 20.1 million metric tons (t) per year and global food fish production has expanded almost 12 times in the past $30 \mathrm{yr}$ at an annual rate of $8.8 \%$ (FAO 2012). However, along with this economic opportunity comes environmental risk.

The United States (U.S.) and other countries endorse a modern marine aquaculture industry that is

(C) The authors 2015. Open Access under Creative Commons by Attribution Licence. Use, distribution and reproduction are unrestricted. Authors and original publication must be credited. 
both profitable and environmentally responsible (NOAA 2011, Subasinghe et al. 2012, National Science and Technology Council Committee on Science Interagency Working Group on Aquaculture 2014). It is necessary to balance the benefits that this industry brings - a safe, nutritious and consistent supply of seafood, jobs and economic opportunity - with a commitment to marine stewardship. To best manage marine resources, coastal stakeholders require tools to evaluate the risks that aquaculture poses in the marine environment and to implement measures which safeguard marine and coastal ecosystems. To achieve an industry that is both profitable and environmentally responsible, the most current knowledge must be readily available to support industrial expansion, guide regulatory processes, inform and reassure the public and strategically direct research.

The real, perceived and potential environmental effects of marine finfish cage aquaculture on water quality are a primary concern of those interested in developing an ecologically responsible industry, and several reviews have broadly addressed this topic (Wu 1995, Goldburg et al. 2001, Pearson \& Black 2001, Hargrave 2003, Goldburg \& Naylor 2005, Braaten 2007, Pittenger et al. 2007, Holmer 2010, Grigorakis \& Rigos 2011). Regional efforts, many sponsored by governmental entities, are also underway to address environmental issues at varying scales (Nash 2001, Wildish et al. 2004, Nash et al. 2005, Huntington et al. 2006, Costa-Pierce et al. 2007, Halwart et al. 2007, IUCN 2007, Olsen et al. 2008).

Waste discharge from marine fish farms can potentially have negative environmental effects that could limit growth of the industry in some areas. Past marine aquaculture practices resulted in environmental degradation, yet in high production areas like northern Europe the industry has largely learned from those mistakes and reduced environmental impacts per unit production largely through a combination of improved feeds and proper siting of farms (Grøttum \& Beveridge 2007). Taken together, lessons learned can be used to develop a framework for siting and operating fish farms that maximize production while minimizing the impact on water quality. However, we lack a comprehensive analysis of how fish farms, as currently operated with modern management practices, have changed in the last 2 decades with regard to reducing potential negative environmental impacts, as well as what issues remain problematic or in need of more research and development efforts. This need for a global, scientific assessment of effects of finfish cage aquaculture prompted us to review recent literature regarding dissolved nutrient load- ing from marine fish farms, direct impacts on water quality, and secondary impacts on primary production, including the formation of harmful algal blooms. Our first goal for this undertaking was to summarize worldwide results from marine fish farm research and monitoring projects that investigated predominant water quality effects including dissolved nitrogen and phosphorus loading, dissolved oxygen depletion, turbidity and lipids, and measurable secondary impacts to primary production. Further, we provide a qualitative analysis of the latest information and scientific research on effects of marine finfish cage culture on water quality and primary production in coastal and ocean environments. Finally, this global perspective supports development of a framework for siting and operating ecologically sustainable fish farms in the USA and worldwide. Effects of particulate waste discharges from fish farms on sediment biogeochemistry, benthic faunal communities, marine biodiversity and sensitive habitats will be reviewed separately in forthcoming papers.

\section{METHODS}

Papers for this review were collected, beginning in early 2011 through 2014, through keyword searches of electronic databases, primarily Aquatic Sciences and Fisheries Abstracts (ProQuest, LLC) and Google Scholar $^{\mathrm{TM}}$. Our aim was to ensure comprehensive coverage, so initial searches included broad keyword combinations such as 'marine aquaculture + nitrogen' and 'marine fish farming + water quality' which were then narrowed down by carefully reviewing abstracts and full text for direct relevance. Colleagues and early reviewers additionally provided recommendations for relevant publications. To provide the needed modern perspective, we limited our review primarily to papers published after 2000 in peer-reviewed journals. We paid particular attention to the peer-reviewed journal literature, but also included material from books and key reports (gray literature) generated by government agencies, academic or research institutions, and private organizations. Only reports with scientific citations and published in English were included. Excluded from our review are opinion pieces, magazine articles, reports without scientific references and papers for which only the abstracts, and not the full manuscripts, were translated into English.

The collected literature-totaling over 180 titlesoriginates from research around the world, covers a 
range of cultured fish species, includes many new farm management approaches, and addresses ecological processes at many scales. The studies here include those that used measurements and changes in concentration as indicators (including bioassays) and studies using modeling approaches to understand interactions between fish farms, water quality and ecological impacts.

\section{FARM NUTRIENT DISCHARGE AND WATER QUALITY}

\section{Nitrogen}

The trend of increasing nitrogen levels in coastal waters due to anthropogenic sources is a concern worldwide, especially because it may cause algal blooms and contribute to nutrient enrichment or eutrophication (Cloern 2001, Galloway et al. 2004, Anderson et al. 2008, Holmer et al. 2008, Tett 2008, Karydis \& Kitsiou 2012). Marine cage aquaculture operations are a recognized source of nitrogenous discharge released both in the form of particulate matter (uneaten food and feces containing undigested food that passes through fish digestive tracts) and dissolved metabolic wastes including ammonia and urea (Cole 2002, Nash et al. 2005, Huntington et al. 2006, IUCN 2007, Pittenger et al. 2007).

\section{Levels of nitrogen discharge}

The amount of nitrogen released from marine fish cages is well documented for various species and marine habitats (Table 1). Wu (1995) and Pearson \& Black (2001) cited nitrogen loss in European salmon Salmo salar farms between 52 and $95 \%$ of the amount contained in feed but noted an improvement due to advances in feeding efficiency. Olsen et al. (2008) constructed a mass balance estimate of nitrogen flow from a hypothetical Norwegian salmon farm producing $1000 \mathrm{t}$ per year. The estimated annual loading rate of $44 \mathrm{~kg}$ of nitrogen per metric ton of fish produced was comparable to rates measured in Scottish farms. Islam (2005) provides a summary of nitrogen budgets in marine cage aquaculture. He reports that $68-86 \%$ of the nitrogen input as feed is eventually released in a dissolved form to the water column. The percentage varies due to the type of feed used, the feed conversion ratio of the cultured organism and feeding efficiency. Strain \& Hargrave (2005) used mass balance calculations to determine that total dissolved nitrogen released from farms in an inlet in southwestern New Brunswick was $33 \mathrm{~kg}$ of waste nitrogen per $\mathrm{t}$ of fish produced. Total annual discharge depended upon production levels (proportional to stock biomass), but was determined to be a significant contributor to nutrient loading compared to other nutrient inputs and natural processes. A nitrogen budget for marine cage culture of mutton snapper Lutjanus analis and cobia Rachycentron canadum showed that $79 \%$ of the nitrogen fed to the fish was released into the water (Alston et al. 2005). More recently, á Norði et al. (2011) calculated that about $63 \%$ of nitrogen in the feed input at a rainbow trout Oncorhynchus mykiss farm in the Faroe Islands was lost as dissolved nitrogen. Using a mass balance approach, Tsagaraki et al. (2011) calculated an annual production of 9-86 t dissolved nitrogenous discharge at 4 Greek fish farms with 100-700 t annual fish production. Bouwman et al. (2013) used a model to estimate that $36 \%$ of the nitrogen in feed is retained in cultured salmon and trout, with $54 \%$ lost as dissolved waste and $10 \%$ as particulates. In a Norwegian fjord supporting $70000 \mathrm{t}$ of salmon production, the Ancylus-MOM Fish model predicted the discharge of $770 \mathrm{t}$ of dissolved inorganic nitrogen (Husa et al. 2014).

Table 1. Nitrogen (N) loading at ocean fish aquaculture sites. Values are presented in the units of the original publication

\begin{tabular}{|lll|}
\hline Loading rate & Species cultured & Reference \\
\hline $770 \mathrm{t}$ N released per 70000 t salmon production & Atlantic salmon & Husa et al. (2014) \\
$64 \% \mathrm{~N}$ in feed lost as dissolved and particulate waste & Atlantic salmon, rainbow trout & Bouwman et al. (2013) \\
$9-86 \mathrm{t}$ l lost per $100-700 \mathrm{t}$ fish production & Sea bass, sea bream & Tsagaraki et al. (2011) \\
$63 \% \mathrm{~N}$ in feed lost as dissolved inorganic N & Rainbow trout & á Norði et al. (2011) \\
$44 \mathrm{~kg} \mathrm{~N}$ released per t of salmon produced & Atlantic salmon & Olsen et al. (2008) \\
$68-86 \%$ N in feed lost as fish waste & Various & Islam (2005) \\
$33 \mathrm{~kg}$ N lost as waste per t of salmon produced & Atlantic salmon & Strain \& Hargrave (2005) \\
$79 \% \mathrm{~N}$ in feed lost as waste & Mutton snapper, cobia & Alston et al. (2005) \\
$52-95 \%$ N in feed lost as waste & Various & Wu (1995), Pearson \& Black (2001) \\
\hline
\end{tabular}


Studies reporting no significant nitrogen increase

Increased dissolved nitrogen discharge to the water column is cited as a major potential impact of marine cage culture (Cloern 2001, Hargrave 2003, Nash et al. 2005, Pittenger et al. 2007, Holmer et al. 2008, Olsen et al. 2008) and its potential to affect water quality have been studied around the world in various marine habitats. In some cases, no increased nutrients in the water column were measureable (Table 2). Tlusty et al. (2005) monitored water quality at Newfoundland salmon farms and found no increased nutrification of the water column despite collecting over 25000 water samples from farm sites with relatively low flushing rates of 5-20 d. Similar results are reported for salmon farms in Chile (Soto \& Norambuena 2004), where no significant increases in dissolved nitrogen concentrations were observed across 9 farm and control sites. Likewise, Nordvarg \& Johansson (2002) concluded that a fish farm in the Baltic's Åland archipelago had no measurable effect on dissolved nitrogen levels. Schembri et al. (2002) reported that no consistent or significant changes to water quality, including dissolved nitrogen levels, were found at a bluefin tuna Thunnus thynnus fattening operation in Malta. Monitoring at a mutton snapper and cobia farm in Puerto Rico showed no differences in dissolved nitrogen between farm and control locations (Alston et al. 2005). Likewise, no increase in dissolved nitrogen was measured at a submersible cage stocked with cobia in the Bahamas (Benetti et al. 2005) or Pacific threadfin Polydactylus sexfilis cages in Hawaii (Helsley 2007). Two studies off the west coast of India found no significant differences in dissolved nitrogen at Asian sea bass Lates calcarifer farms compared to reference stations (Prema et al. 2010, Philipose et al. 2012).

\section{Studies reporting measurable discharge}

Other studies have reported elevated dissolved nitrogen concentrations around fish farms, but impacts were considered negligible. For example, á Norði et al. (2011) measured dissolved ammonium levels up to 4.3 times higher near fish pens than at reference stations away from farm sites, but concentrations were typical of those at efficiently

Table 2. Levels of dissolved nitrogen discharge reported and modeled at fish cage sites. At sites with minimal impact levels, the authors reported measurable increases in dissolved nitrogen, but these were statistically insignificant or were not thought to have significant environmental implications

\begin{tabular}{|c|c|c|c|}
\hline Impact level & Location & Species cultured & Reference \\
\hline \multirow[t]{9}{*}{ None detected } & Canada & Atlantic salmon & Tlusty et al. (2005) \\
\hline & Chile & Atlantic salmon & Soto \& Norambuena (2004) \\
\hline & Baltic Sea & Atlantic salmon & Nordvarg \& Johansson (2002) \\
\hline & Hawaii & Pacific threadfin & Helsley (2007) \\
\hline & Puerto Rico & Mutton snapper, cobia & Alston et al. (2005) \\
\hline & The Bahamas & Cobia & Benetti et al. (2005) \\
\hline & Malta & Bluefin tuna & Schembri et al. (2002) \\
\hline & India & Sea bass & Prema et al. (2010) \\
\hline & India & Sea bass & Philipose et al. (2012) \\
\hline \multirow[t]{10}{*}{ Minimal } & Faroe Islands & Atlantic salmon & á Norði et al. (2011) \\
\hline & Puget Sound & Atlantic salmon & Rensel et al. (2007) \\
\hline & USA & Atlantic salmon & Sowles (2005) \\
\hline & Pacific Northwest & Atlantic salmon & Nash et al. (2005) \\
\hline & Greece & Sea bass, sea bream & Tsagaraki et al. (2011) \\
\hline & Adriatic Sea & Sea bass, sea bream & Matijevic et al. (2009) \\
\hline & Aegean Sea & Sea bass, sea bream & Neofitou \& Klaoudatos (2008) \\
\hline & Aegean Sea & Sea bass, sea bream & Mantzavrakos et al. (2005) \\
\hline & Aegean Sea & Sea bass, sea bream & Pitta et al. (2005) \\
\hline & Italy & Sea bass, sea bream & Doglioli et al. (2004) \\
\hline \multirow[t]{6}{*}{ Significant } & Mediterranean & Bluefin tuna & Aguado-Giménez et al. (2006) \\
\hline & Mediterranean & Sea bass, sea bream & Dalsgaard \& Krause-Jensen (2006) \\
\hline & Taiwan & Unknown & Hung et al. (2008) \\
\hline & Australia & Barramundi & McKinnon et al. (2008) \\
\hline & Canada & Atlantic salmon & Strain \& Hargrave (2005) \\
\hline & China & Unknown & Jiang et al. (2012) \\
\hline
\end{tabular}


flushed farm locations and no stimulation of primary production was evident. In the Mediterranean, Neofitou \& Klaoudatos (2008) measured elevated nitrogen at sea bass Dicentrarchus labrax and sea bream Sparus auratus cages in the Aegean Sea. Levels decreased quickly downstream of the cages $(300 \mathrm{~m})$, however, and were always within ranges of nutrient concentrations measured in similar regions of the eastern Mediterranean Sea. Also in the Aegean Sea, Pitta et al. (2005) compared water column effects in farmed and reference sites and found significantly elevated nitrogen levels in bottom water $(10 \mathrm{~m})$ during September. However, they concluded that nitrogen concentrations were within the normal range of values reported for the Aegean and speculated that the higher concentrations may have been due to resuspension of sediments below the thermocline. Surface and midwater levels of nitrogen were not significantly different from reference areas without fish farming. In another study at northwestern Aegean sea bream and sea bass farms, increased nitrogen concentrations were found close to cages, but concentrations decreased to background levels within $30 \mathrm{~m}$ of the farm (Mantzavrakos et al. 2005). Doglioli et al. (2004) modeled the regional dispersion patterns

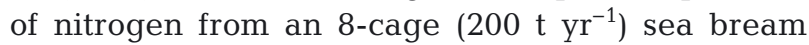
and sea bass farm near the Italian coast. They concluded that dissolved nitrogen levels remained low in this area due to flushing by strong currents. Predicted results agreed well with field sampling, validating their model. In an Adriatic sea bass and sea bream farm, Matijevic et al. (2009) reported slightly elevated dissolved nitrogen at farm versus reference sites, predominantly in surface $(0-20 \mathrm{~m})$ waters. In a model validation study in Greece, both field samples and modeled scenarios reflected increased dissolved nitrogen around fish farms, but local hydrodynamic conditions provided sufficient flushing to maintain water quality (Tsagaraki et al. 2011). In Maine, Blue Hill Bay was assessed to determine the feasibility of adding more salmon culture cages (Sowles 2005). While nitrogen levels in the bay were found to be elevated due to aquaculture, the researcher concluded the bay had the capacity to assimilate additional nitrogen loading from expansion of fish farming without the risk of increased primary production. Modeling (using AquaModel® software) to assess the feasibility of establishing cage farms in the Straits of Juan de Fuca predicted that nitrogen would increase in the farm plume, but did not predict enrichment or phytoplankton blooms (Rensel et al. 2007). Nash et al. (2005) concluded that extensive monitoring of net pens in Europe, Canada and the USA indicated only modest increases in dissolved nitrogen around fish cages, with farmers locating farms in well-flushed areas to avoid seasonal nutrient enrichment.

\section{Studies reporting significant nitrogen increase}

Some research studies have found significant increases in dissolved nitrogen. For example, AguadoGiménez et al. (2006) calculated the estimated dissolved nitrogen outputs of a bluefin tuna fattening operation in the Mediterranean could be 2-5.6 times greater than a comparable sea bream farm, with the potential for significant environmental impacts during peak production periods. Dalsgaard \& Krause-Jensen (2006) conducted bioassays using macroalgae and phytoplankton at 4 sea bream and sea bass farms in the Mediterranean. For both algae and plankton, growth was highest at cage sites and elevated within $150 \mathrm{~m}$ of the cages. Tissue nitrogen content of the algae was highest in samples growing closest to the cages, indicating a clear transfer of nitrogen from the farm to the adjacent water to pelagic primary producers. In Tapong Bay, Taiwan (Hung et al. 2008), removal of mariculture structures from the semi-enclosed lagoon after decades of farming resulted in a significant decrease in dissolved nitrogen in the water column contributing to an overall improvement in ecosystem quality. Monitoring at a barramundi Lates calcarifer farm in Queensland, Australia, showed elevated dissolved nitrogen concentrations that exceeded trigger values set in the Queensland Water Quality Guidelines (McKinnon et al. 2008). High nitrogen levels were measured during the wet season and nitrogen flux was locally regulated by mangrove trees. Nash et al. (2005) suggested that dissolved nutrient release may affect attached macroalgae, but that if eutrophication due to aquaculture does occur, it would be at locations distant from a farm (far-field) rather than at a local scale due to dispersal of dissolved nutrients by currents. A study in China comparing nutrient levels inside and $1000 \mathrm{~m}$ away from fish farms found that dissolved nitrogen doubled at the farms during warmer seasons, potentially contributing to eutrophication in the area (Jiang et al. 2012). Pittenger et al. (2007) concluded that discharges from farms, including nitrogen, represented a significant influx of nutrients to the marine environment. 


\section{Phosphorus}

Although nitrogen is generally the limiting nutrient in marine waters, the trend of increasing phosphorus levels in coastal waters due to anthropogenic sources is also of concern because primary production in some marine systems such as tropical waters is phosphorus limited. In these cases, increased phosphorus may contribute to algal blooms and eutrophication (Cloern 2001, Nordvarg \& Hakanson 2002). Similar to nitrogen, phosphorus is released from fish farms in uneaten food, undigested food that passes through fish digestive tracts, and as dissolved phosphate in metabolic wastes.

\section{Levels of phosphorus discharge}

Environmental impact studies of marine cage culture tend to include less information about phosphorus than nitrogen. Wu (1995) reported that up to $82 \%$ of the phosphorus in fish feed was lost to the environment while Pearson \& Black (2001) found that $34-41 \%$ of phosphorus in feed was released in dissolved form (Table 3). More recently, Islam (2005) compiled phosphorus budgets of marine cage aquaculture and reported that an average of $71.4 \%$ was released to the environment. The percentage varied with species cultured, type of feed used, feed conversion ratio and feeding efficiency. Strain \& Hargrave (2005) used mass balance calculations to estimate the total fish farm derived nutrient output from salmon aquaculture in different inlets in the Bay of Fundy. Total dissolved phosphorus released from farms was calculated as $4.9 \mathrm{~kg}$ of waste phosphorus per $\mathrm{t}$ of fish produced. Total discharge depended upon production levels, but was determined to be a significant contributor to nutrient loading in some of the inlets where water exchange is more limited. Tsagaraki et al. (2011) calculated an annual production of 0.6-6.5 t dissolved phosphorus discharge at 4 Greek fish farms with 100-700 t annual fish production. Bouwman et al. (2013) applied modeling to estimate $27 \%$ of the phosphorus consumed by salmon and trout in feed is lost as dissolved waste and $40 \%$ is discharged as particulates, while only $33 \%$ is retained. The AncylusMOM Fish model, when applied in a Norwegian fjord supporting $70000 \mathrm{t}$ of salmon production, predicted the discharge of $127 \mathrm{t}$ of dissolved inorganic phosphorus (Husa et al. 2014).

Studies reporting no significant phosphorus increase

The release of phosphorus into ocean waters and the potential for deleterious nutrification effects continues to be the subject of monitoring and modeling studies in marine ecosystems around the world. As for dissolved nitrogen, results show different effects in different areas (Table 4). Two years of monitoring nutrients at salmon farms in a Newfoundland fjord found no changes in water quality due to farm discharge (Tlusty et al. 2005). Soto \& Norambuena (2004) evaluated 29 salmon farm sites in Chile and found no effect of farming on dissolved phosphorus concentrations which were comparable to reference locations. Schembri et al. (2002) reported that no consistent or significant changes to water quality, including dissolved phosphorus levels, occurred at a tuna fattening operation in Malta. Similarly, sampling at Mediterranean fish farms (Pitta et al. 2005) showed that there was no increase in dissolved phosphorus compared to reference areas. A simulation model of the Straits of Juan de Fuca (Rensel et al. 2007) predicted no adverse effects to water quality due to fish farming, especially as sunlight is thought to be the limiting factor for primary production in that body of water. Dissolved phosphorus from salmon farms in the Pacific Northwest was not identified as a concern by Nash (2001), primarily because the system is nitrogen limited. Studies at fish farms in Hawaii (Helsley 2007), The Bahamas (Benetti et al. 2005) and Puerto Rico (Alston et al. 2005)

Table 3. Phosphorus (P) loading at ocean fish aquaculture sites. Values are presented in the units of the original publication

\begin{tabular}{|lll|}
\hline Loading rate & Species cultured & Reference \\
\hline 127 t P released per 70000 t salmon production & Atlantic salmon & Husa et al. (2014) \\
$67 \%$ P in feed lost as dissolved and particulate waste & Atlantic salmon, rainbow trout & Bouwman et al. (2013) \\
$0.6-6.5$ t P lost per 100-700 t fish production & Sea bass, sea bream & Tsagaraki et al. (2011) \\
$71.4 \%$ P in feed lost as waste & Various & Islam (2005) \\
$4.9 \mathrm{~kg}$ P lost as waste per t of salmon produced & Atlantic salmon & Strain \& Hargrave (2005) \\
$34-41 \%$ P in feed lost as dissolved P & Various & Pearson \& Black (2001) \\
$82 \%$ P in feed lost as waste & Salmonids & Wu (1995) \\
\hline
\end{tabular}


Table 4. Levels of dissolved phosphorus discharge reported and modeled at fish cage sites. At sites with minimal impact levels, the authors reported measurable increases in dissolved phosphorus, but these were statistically insignificant or were not thought to have significant environmental implications

\begin{tabular}{|llll}
\hline \multirow{2}{*}{ Impact level } & Location & Species cultured & Reference \\
\hline None detected & Canada & Atlantic salmon & Tlusty et al. (2005) \\
& Chile & Atlantic salmon & Soto \& Norambuena (2004) \\
& Pacific Northwest & Atlantic salmon & Nash (2001) \\
& Puerto Rico & Mutton snapper, cobia & Alston et al. (2005) \\
& The Bahamas & Cobia & Benetti et al. (2005) \\
& Hawaii & Pacific threadfin & Helsley (2007) \\
& India & Sea bass & Philipose et al. (2012) \\
& India & Sea bass & Prema et al. (2010) \\
& Aegean Sea & Sea bass, sea bream & Pitta et al. (2005) \\
& Malta & Bluefin tuna & Schembri et al. (2002) \\
& Greece & Sea bass, sea bream & Tsagaraki et al. (2011) \\
& Aegean Sea & Sea bass, sea bream & Neofitou \& Klaoudatos (2008) \\
& Adriatic Sea & Sea bass, sea bream & Matijevic et al. (2009) \\
& Aegean Sea & Sea bass, sea bream & Mantzavrakos et al. (2005) \\
& Italy & Sea bass, sea bream & Doglioli et al. (2004) \\
& USA & Atlantic salmon & Sowles (2005) \\
& Australia & Barramundi & McKinnon et al. (2008) \\
& Canada & Atlantic salmon & Strain \& Hargrave (2005) \\
& Baltic Sea & Atlantic salmon & Nordvarg \& Johansson (2002) \\
& Mediterranean & Bluefin tuna & Piedecausa et al. (2010) \\
& Mediterranean & Bluefin tuna & Aguado-Giménez et al. (2006) \\
& Mediterranean & Sea bass, sea bream & Dalsgaard \& Krause-Jensen (2006) \\
& Taiwan & Unknown & Hung et al. (2008) \\
& China & Unknown & Jiang et al. (2012) \\
& & &
\end{tabular}

showed no significant increases in dissolved phosphorus near cages. Two studies off the west coast of India found no significant differences in dissolved phosphorus at sea bass farms compared to reference stations (Prema et al. 2010, Philipose et al. 2012).

Studies reporting measurable phosphorus discharge

Many published articles conclude that even when there is evidence of increased dissolved phosphorus at or near fish farms, the impacts are confined to waters adjacent to net pens and are short-lived or seasonal. For example, Neofitou \& Klaoudatos (2008) found differences in dissolved phosphorus at fish farms in the Aegean Sea, but effects were confined to within $300 \mathrm{~m}$ of the cages and levels did not exceed those that could lead to eutrophication. At Greek sea bream and sea bass farms, sampling stations closest to farms had increased dissolved phosphorus, but levels were decreased at $30 \mathrm{~m}$ from the cages (Mantzavrakos et al. 2005). Doglioli et al. (2004) modeled the dispersion of nutrients from aquaculture cages in the Italian Mediterranean, predicting that prevailing currents provided sufficient flushing. Com- parison with field data verified that phosphorus levels in the water due to fish farming remained very low. Sampling at sea bream and sea bass farms in the Adriatic showed that dissolved phosphorus concentrations were only slightly elevated at farm versus reference stations, and only in the upper water column (Matijevic et al. 2009). Field samples and modeled scenarios in a study at Greek sea bass and sea bream farms found there was increased dissolved phosphorus around fish farms, but concluded that there was sufficient local flushing to maintain water quality (Tsagaraki et al. 2011). An assessment of the nutrient profiles, including phosphorus, in Blue Hill Bay, Maine, concluded that the bay could assimilate phosphorus from additional net pens (Sowles 2005). Monitoring at a barramundi farm in Queensland, Australia (McKinnon et al. 2008) found seasonally elevated dissolved phosphorus levels, but these did not exceed governmental water quality threshold values.

Studies reporting significant phosphorus increase

In contrast, some published papers document significantly increased dissolved phosphorus levels due 
to marine fish farming. Dalsgaard \& Krause-Jensen (2006) used macroalgal and phytoplankton assays to monitor nutrient release at fish farms in the Mediterranean. Growth was higher in samples taken closest to the fish cages, suggesting that nutrients would be locally available for primary production. The phosphorus output from a tuna fattening operation was calculated to be about 3-5 times higher than from sea bream or sea bass farms because of differences in digestibility and feed formulation (Aguado-Giménez et al. 2006). The cessation of aquaculture activities in the semi-enclosed Tapong Bay, Taiwan, resulted in significantly decreased dissolved phosphorus levels and improved overall environmental quality (Hung et al. 2008). Dissolved phosphorus levels in a study in China comparing nutrient levels inside and $1000 \mathrm{~m}$ away from fish farms found that dissolved phosphorus increased at the farms during warmer seasons, possibly contributing to eutrophication in the bay where the farms were sited (Jiang et al. 2012). Nordvarg \& Johansson (2002) measured phosphorus at farm sites in the Åland archipelago in the Baltic Sea. They found that farms in semi-enclosed bays had elevated levels, as did some areas during high fish production, concluding that fish farming may have significant impacts on coastal areas. Complementing this work, Nordvarg \& Håkanson (2002) developed a mass balance model for phosphorus in this archipelago to be used for siting farms in nutrient sensitive areas. Model simulations comparing phosphorus outputs from sea bream, sea bass and Atlantic bluefin tuna (Piedecausa et al. 2010) indicated significant differences in nutrient waste production among species - with the tuna being the highest - which must be taken into account when managing the marine environment for multiple aquaculture facilities.

In summary, increased dissolved phosphorus is generally not considered a serious concern for marine cage aquaculture (Nash et al. 2005, Costa-Pierce et al. 2007) because primary production in most marine waters is nitrogen, not phosphorus, limited. As with nitrogen, dispersive currents flushing nutrients away from the immediate cage perimeter minimize measurable local impacts close to cages. Usually, changes in nitrogen and phosphorus levels near fish farms are simultaneously detectable or not. However, there are cases in which increases in one dissolved nutrient are not comparable to changes in the other (Schembri et al. 2002, Pitta et al. 2005), with nitrogen being the more elevated nutrient. There is need for studies investigating possible cumulative impacts to downstream areas, especially in regions that contain multiple operational farms.

\section{Dissolved oxygen}

Sufficient dissolved oxygen in the water column is essential to aquaculture operations and has been extensively studied and monitored in all types of culture operations. Oxygen concentrations in the water column near farm operations are lowered primarily through fish respiration, but also due to microbial metabolism. In Wu's (1995) summary of environmental impacts of marine fish cage culture he reported localized or insignificant effects on dissolved oxygen. Yet, concern remains that marine cage culture may significantly decrease dissolved oxygen concentrations sufficiently to cause local short-term negative effects (IUCN 2007, Pittenger et al. 2007, Tett 2008).

\section{Studies reporting no significant decrease}

Several recent studies examined the effects of ocean cage culture on dissolved oxygen to evaluate the potential for decreased oxygen concentration near fish farms. Several reported no significant effects of marine cage culture on dissolved oxygen. A meta-analysis of 30 peer-reviewed articles (Sarà 2007) concluded that dissolved oxygen was generally not affected by aquaculture operations. In the Aegean Sea, tuna and sea bass farms were monitored (Basaran et al. 2007, Yabanh \& Egemen 2009, Aksu et al. 2010), with no effects detected. VargasMachuca et al. (2008) found no impacts on dissolved oxygen at snapper farms off Mexico's Pacific coast. In their assessment of Pacific Northwest salmon farms, Brooks \& Mahnken (2003) found little risk to the environment from dissolved oxygen depletion. No significant effects on dissolved oxygen levels were observed in studies at submerged cobia cages in Puerto Rico and the Bahamas where concentrations were consistently $>5 \mathrm{mg} \mathrm{l}^{-1}$ (Alston et al. 2005, Benetti et al. 2010). In Scotland, modeling was used to predict the likely effects of fish farming on biological oxygen demand in 135 loch basins to assess the risk of oxygen depletion in these deep water environments (Gillibrand et al. 2006). The results suggested that farming was unlikely to contribute significantly to hypoxic events in the majority of lochs. Two studies off the west coast of India generally found no differences in dissolved oxygen at sea bass farms compared to reference stations, though 1 fish mortality event occurred during a period of low dissolved oxygen in the summer (Prema et al. 2010, Philipose et al. 2012). 
Studies reporting significant decrease in dissolved oxygen

In contrast to the above studies which found no effects on dissolved oxygen, 3 studies on the northeastern coast of North America reflect the potential of marine cage culture to impact dissolved oxygen (Hargrave 2005). Page et al. (2005) summarized monitoring efforts in southwestern New Brunswick. Decreased oxygen concentrations were measured in and near salmon cages with the greatest declines occurring within fish cages located in areas where rates of tidal flushing were low. The researchers calculated an oxygen depletion index to model the potential for caged fish to deplete oxygen concentrations at multiple scales under varying flushing regimes. Farmers and regulators could use the approach for siting decisions and to determine optimal stocking density to avoid oxygen depletion. Strain \& Hargrave (2005) modeled nutrient fluxes and ecosystem processes around salmon farms in the Bay of Fundy. Their mass balance calculations showed that in some embayments salmon in net-pens could decrease oxygen concentration by up to $1.4 \mathrm{mg} \mathrm{l}^{-1}$ around individual farms, but concluded that inletwide ecosystem effects were likely minimal. Sowles (2005) investigated water quality parameters as part of an assessment of current and potential aquaculture impacts in Blue Hill Bay, Maine. Dissolved oxygen concentrations varied seasonally and spatially within the bay, but were always above the threshold value of $6 \mathrm{mg} \mathrm{l}^{-1}$ where negative effects would not be expected. Dissolved oxygen at a rainbow trout farm in the Faroe Islands decreased by $11-26 \%$ from July to September compared to a reference station, although generally the water was supersaturated (á Norði et al. 2011). The decreased oxygen levels were due to fish respiration and current velocity was sufficient to avoid severe oxygen depletion. A study in Turkey's Güllük Bay (Demirak et al. 2006) monitored dissolved oxygen at 7 sea bass cages and 3 control sites. Dissolved oxygen at the cage sites was significantly lower than at control sites, but remained $>4 \mathrm{mg} \mathrm{l}^{-1}$, a threshold for the onset of stress for many marine fish species. Decreased dissolved oxygen was also observed during monitoring studies at barramundi cage sites in Queensland, Australia, but the extent and severity were not considered to be a threat to the farmed fish or local environment (McKinnon et al. 2008). Nash et al. (2005) found that long-term monitoring in the northeast Pacific showed maximum dissolved oxygen reductions of $2 \mathrm{mg} \mathrm{l}^{-1}$ only occurred under cages with high densities of fish.
Overall, however, dissolved oxygen reduction in most cages was $<0.5 \mathrm{mg} \mathrm{l}^{-1}$ below saturation.

In general, changes in dissolved oxygen are not detected or are negligible in and around offshore fish farms (Braaten 2007). Seasonal, tidal and diurnal fluxes often cause more changes in dissolved oxygen than do fish farms. Thus, proper siting of farms in areas with sufficient flushing rates is recommended. Oxygen bubblers (Srithongouthai et al. 2006, Endo et al. 2008), mechanical aeration (Goldburg \& Triplett 1997) and lowering sea cages below the ocean surface (Dempster et al. 2009) are management tools that can be implemented on farms to minimize or eliminate dissolved oxygen depletion, but may not be feasible at remote ocean sites due to lack of electricity.

\section{Turbidity and lipids}

Particulates or dust from feed, and fish waste (feed pellets and feces) are 2 primary sources of turbidity associated with cage culture (Pergent et al. 1999, Ruiz et al. 2001, Hargrave 2003, IUCN 2007). Scraping of biofouling may also result in a temporary decrease in water clarity (Hargrave 2003, Alston et al. 2005). In general, high flushing rates will minimize increases in turbidity at cage sites. In contrast, when flushing rates are low due to tidal or seasonal shifts in water currents (Tanaka \& Kodama 2007, McKinnon et al. 2008) or due to siting in areas with decreased flow, feed and waste suspended in the water column may increase turbidity. However, shortterm turbidity spikes are considered unlikely to have lasting impacts on water quality or biodiversity.

Prolonged changes in turbidity associated with freshwater aquaculture facilities have been documented (Sarà 2007), but less data are available for open ocean cage culture. Increased turbidity may result in lower light penetration affecting phytoplankton production (Harrison et al. 2005) and may affect photosynthesis of benthic aquatic vegetation like seagrasses (Cole 2002). Because of high flushing rates in open ocean conditions, turbidity is generally more of a potential concern at nearshore sites than open ocean sites. This is especially true in coastal waters in the vicinity of critical habitats such as corals and seagrass beds, which can be light limited. A recent study conducted at salmon cages in Maine (Sowles 2005) found that light penetration levels (an indicator of turbidity) at both cage and control sites met water quality targets for transparency. An environmental assessment of a barramundi farm in Queensland, Australia (McKinnon et al. 2008) reported turbidity 
differences between cage and control sites; however, these were transient, and the authors attributed them to seasonal and tidal differences in flushing rather than aquaculture operations. Conversely, Harrison et al. (2005) report that in southwestern New Brunswick, Canada, Secchi depth readings near salmon pens were significantly lower than at control sites. Similarly, Secchi readings at sea bass and sea bream sites in Turkey were lower than at 3 control stations (Aksu \& Kocatas 2007), but this report did not include a statistical analysis for significance. Turbidity values around cages at a cobia farm in Puerto Rico were normal and did not differ from the control site (Alston et al. 2005).

Generally, turbidity impacts at open ocean cage sites were not included among high priority concerns in the reviewed literature. Proper siting to ensure flushing and improvements in feed composition and feeding efficiency that reduce feed waste are general management guidelines recommended to minimize aquaculture effects on turbidity. Using fish feed with low fines (i.e. feed dust particulates) will also minimize turbidity effects. The extent to which different automated feeding systems erode feed, create dust particles and possibly affect turbidity is uncertain.

Lipids are an essential component of fish feeds and are cited as a source of organic waste at fish farms (Hargrave 2003, Nash et al. 2005, Huntington et al. 2006, Trushenski et al. 2006, Pittenger et al. 2007, Rust et al. 2011). Fish feeds vary significantly in composition, with lipids comprising 4-40\% (Tucker \& Hargreaves 2008) of commercial diets. As the industry has expanded, so has the amount of fish oil released in feed products (Pittenger et al. 2007). Advances in feed formulation have resulted in considerable vegetable oil replacement of fish oil in feed (Nash et al. 2005, Rust et al. 2011).

Little research or monitoring data is available directly addressing lipid levels in the water within or near marine cages. Cole (2002) reported that at fish farm sites in New Zealand lipids were often seen floating on the surface after feeding. Klaoudatos (2000) reported the mean lipid output from a $200 \mathrm{t}$ cage fish farm in Greece was $0.357 \mathrm{~kg} \mathrm{~d}^{-1}$. This is the only study known to have reported a value for lipid release from any aquaculture cage site. (Bodennec et al. 2002) found that 3 ichthyotoxic algal species grown in media supplemented with fish feed showed altered lipid composition which could increase their toxicity. Lipids as surface or water column pollutants do not appear to be a primary concern for the study of environmental impacts of feed products. Yet, due to buoyancy, lipids released from a farm site can be expected to disperse widely in the sea surface microlayer as it is moved by wind and tidal action. More research is required to determine whether the sea surface microlayer is a significant transport pathway for dispersal of waste from fish cages (Loucks et al. 2012).

\section{SECONDARY IMPACTS FROM DISSOLVED NUTRIENT DISCHARGE}

Few long-term studies document clear trends of increasing nutrient levels with primary productivity in coastal waters, even though increased eutrophication has been reported in some areas with nitrogen and phosphorus fluxes elevated by an estimated 2-14 times the natural rates (Cloern 2001). Furthermore, it is difficult to link any such effects specifically to aquaculture (Wu 1995, Pearson \& Black 2001). As discussed above, dissolved nitrogen and phosphorus discharge from fish farms may or may not be measurable in surrounding waters, but often secondary impacts resulting from nutrient enrichment are of greater concern (Yucel-Gier et al. 2011). The potential for negative effects on marine biodiversity is often identified as a foremost concern of marine managers, scientists and regulatory agencies. Nutrient enrichment and potential eutrophication related to marine fish farm effluents are important issues raised in the USA (Goldburg et al. 2001, Nash 2001, Nash et al. 2005, Pittenger et al. 2007, Johnson et al. 2008), Canada (Hargrave 2003, Strain \& Hargrave 2005), South America (Costa-Pierce et al. 2007, Buschmann et al. 2009), the European Union (Black et al. 2002, ICES 2002, Huntington et al. 2006, Holmer et al. 2008, Olsen et al. 2008, Tett 2008, Holmer 2010), the Mediterranean (IUCN 2007, MSC 2007, Borg et al. 2011, Karydis \& Kitsiou 2012) and globally (Beveridge 2004, Halwart et al. 2007, Tucker \& Hargreaves 2008, Ross et al. 2013a).

Because some coastal areas are nutrient limited, it is possible that elevated nitrogen and phosphorus contribute to increases in phytoplankton and macroalgae production. In most marine waters, nitrogen is the limiting nutrient, but there are waters (some estuarine and tropical waters, for example) where phosphorus or abiotic seasonal factors like light are influential in driving primary productivity. We reviewed current research investigating potential links between aquaculture effluent and increased primary production. Special attention is given to the issue of harmful algal blooms (HABs) - both the potential causes of HABs by fish farm waste and potential HAB impacts on fish farms. 


\section{Primary production}

Studies reporting no significant impacts

Many studies have been unable to detect a phytoplankton response tied to nutrient loading from fish farm effluent (Table 5), especially in oligotrophic waters (Braaten 2007, Holmer et al. 2008, Holmer 2010). This is probably because such effects are inherently unlikely if the residence time of the water body is lower than the generation time of phytoplankton. In the USA, monitoring at a cobia farm off Puerto Rico found no differences in chlorophyll a (chl a) concentrations at the cage versus control sites (Alston et al. 2005). Similar monitoring results were reported at a Hawaiian moi Polydactylus sexfilis farm (Helsley 2007) and an experimental cage in the Bahamas (Benetti et al. 2005). Monitoring in Blue Hill Bay, Maine, also did not show increased chlorophyll concentrations in proximity to fish farms (Sowles 2005). Likewise, 2 years of extensive sampling near salmon farms in 3 New Brunswick bays found no increase in chlorophyll concentrations compared with control sites due to strong tidal mixing (Harrison et al. 2005). It is likely that light, rather than nutrient loading, was the limiting factor driving primary production in the turbid water in this bay.

An evaluation of 43 salmon farm sites in Chile did not detect any effect of farm effluent on chlorophyll levels compared to control sites (Soto \& Norambuena 2004). This analysis included farms of varying ages and production levels at 9 locations. The farms were all located in deep water (15-94 m) and rapid flushing of nutrients likely explained the lack of an effect on primary production.

Water sampling at a salmon farm in Scotland detected locally increased nutrient levels, but showed no differences in chl a compared to a control site $650 \mathrm{~m}$ away (Navarro et al. 2008). These results support the conclusions of previous studies that there is no consistent effect of farm nutrient enrichment on primary productivity. In fact, fish farming is considered to pose little risk of increased primary production in most Scottish waters, apart from a few sea lochs with many farm sites (Black et al. 2002). Heath et al. (2003) applied the European Regional Seas Ecosystem model (ERSEM) to identify areas of Scotland's maritime regions that may be at risk of eutrophication, with special focus on the contribution of salmon farms to nutrient loading. They concluded that the nutrients released from aquaculture sites caused no discernible eutrophication in the west and north coastal and offshore waters. Recently, Tett et al. (2011) tested a computational physical-biological model, ACExR-LESV, for estimating the aquaculture carrying and assimilative capacities of Scottish fjords. Modeling output from a simulated loch was compared to water quality indicators and standards to

Table 5. Summary of primary production effects reported and modeled at fish cage sites in response to farm nutrient discharge

\begin{tabular}{|llll}
\hline \multirow{2}{*}{ Impact level } & Location & Species cultured & Reference \\
\hline None detected & Puerto Rico & Cobia & Alston et al. (2005) \\
& Hawaii & Moi & Benetti et al. (2005) \\
& Norway & Salmon & Husa et al. (2014), Skaala et al. (2014) \\
& Maine & Salmon & Sowles (2005) \\
& New Brunswick & Salmon & Harrison et al. (2005) \\
& Chile & Salmon & Soto \& Norambuena (2004) \\
& Scotland & Salmon & Navarro et al. (2008) \\
& Spain & Sea bass, sea bream & Maldonado et al. (2005) \\
& Turkey & Sea bass, sea bream & Basaran et al. (2010) \\
& Turkey & Sea bass, sea bream & Belias et al. (2003) \\
& Greece & Sea bass, sea bream & Vezzulli et al. (2008) \\
& Italy & Tuna & Robinson et al. (2005) \\
& Bay of Fundy & Salmon & Rensel \& Forster (2007) \\
& Puget Sound & Salmon & Honkanen \& Helminen (2000) \\
& Finland & Tsagaraki et al. (2013) \\
& Greece & Sea bass, sea bream & Tsagaraki et al. (2011) \\
& Greece & Sea bass, sea bream & Sara et al. (2011) \\
& Sicily & Sea bass, sea bream & Modica et al. (2006) \\
& Sicily & Sea bass, sea bream & Vizzini \& Mazzola (2006) \\
& Mediterranean & Sea bass, sea bream & Huang et al. (2011) \\
& South China Sea & Various & Jiang et al. (2012) \\
& China & Sun et al. (2011) \\
& China & Unknown & Iriarte et al. (2013) \\
& Chile & Mesocosms &
\end{tabular}


decide how many fish farms the loch could support sustainably. The modeled carrying capacity was strongly driven by light penetration and circulation patterns that minimized chlorophyll production. This model requires further refinement before it can be reliably applied.

A comprehensive study in an intensively farmed Norwegian fjord, found no impacts on chl a or macroalgal abundance and species diversity, with the fjord being classified as having high quality ecological status (Husa et al. 2014, Skaala et al. 2014). This effort was part of a multi-disciplinary research program established to learn more about the interactions between human activities (e.g. aquaculture, hydropower, household pollution and climate change) and the fjord ecosystem.

A study in Spain compared chl a levels in the sediment below 5 sea bass and sea bream fish farms (Maldonado et al. 2005). Overall chlorophyll levels remained low $\left(<2 \mu \mathrm{g} \mathrm{g}^{-1}\right)$ and, while some variability between farms was evident, there were no detectable differences between farm and reference sites. Demirak et al. (2006) found no difference in chl a level at 7 Turkish fish farm sites compared to reference sites. Similarly, Basaran et al. (2010) did not detect a significant difference in chlorophyll concentrations at 8 sea bream and sea bass farms off Turkey compared to a control station. No eutrophication effects were found at a sea bass and sea bream farm in Greece (Belias et al. 2003), possibly due to overall low nutrient levels. However, the alga Ulva lactuca has recently been found in several parts of the Astakos Gulf, possibly signaling increased nutrient loading. Vezzulli et al. (2008) tested chl a levels in the water and sediments at a bluefin tuna farm in Italy. Only seasonal differences in concentrations were detected and the authors conclude that the water speed and depth at the farm site were adequate to prevent increased primary production. Likewise, no differences in chl $a$ were detected during long-term monitoring at a tuna farm in Turkey compared with reference sites (Aksu et al. 2010).

\section{Studies reporting significant increase in primary production}

In contrast to the above studies, there is evidence that nutrification at some fish farms can lead to increased primary productivity. For example, Robinson et al. (2005) studied the far-field effects on macroalgal production in intertidal areas near salmon farms in the Bay of Fundy. Eutrophication in one intertidal area $1 \mathrm{~km}$ from a farm site resulted in the growth of extensive algal mats along the shoreline, threatening a native soft clam fishery. The estimated economic direct loss of clams at one site was calculated at $\$ 168000$ (Canadian). The appearance of these algal mats in the mid-1990s coincided with the development of salmon farming in nearby waters. Aerial photography showed that at times the mats covered up to $40 \%$ of the beach for an estimated algal biomass production of $59 \mathrm{t}$. Rensel \& Forster (2007) documented over 29 species of algae growing on net pens, floats and anchor lines at a salmon farm in Puget Sound. Algal growth was linked to the farm effluent by nitrogen and carbon isotope analysis. The authors consider such biocolonization an environmental benefit to the marine ecosystem (i.e. primary production, providing food and habitat), and some colonizing algae could even have commercial value.

Honkanen \& Helminen (2000) found increased chl a concentrations near 7 fish farms in 2 Finnish straits. Suspended pigment concentrations and algal growth on plates suspended in the water column were higher near the farms, but neither dissolved nitrogen nor phosphorus varied consistently with distance from the cages. In the Baltic Sea, Nordvarg \& Håkanson (2002) observed nutrient concentrations and deployed algal growth plates at 10 salmon farm areas and 4 control areas to assess effects of nutrient release and primary productivity response. The presence of fish farms increased both chl a levels and periphyton growth at only a few locations. Local hydrogeology was thought to be the most influential factor in determining whether a measureable effect on primary production occurred. Affected sites were in semi-enclosed, shallow bays. The data were further used to develop and validate a model to predict nutrient and chl a dynamics in the area.

In the eastern Mediterranean, Pitta et al. (2009) used dialysis bag experiments to demonstrate that nutrients from sea bass and sea bream farms were being transferred up the food chain by phytoplankton grazers. Chl $a$ and nitrogen levels were higher in bags containing water filtered to remove grazers suspended near the farms and concentrations decreased with increasing distance to $500 \mathrm{~m}$. In bags with grazers, chl a was lower presumably due to planktivory. The authors suggested that rapid transfer of nutrients to higher trophic levels is possible in oligotrophic waters. Such fertilization by fish farms may be perceived as a positive contribution to nutrient poor marine environments (Rensel \& Forster 2007), provided that it does not exceed the assimilative capacity of the ecosystem. 
A study in Sicily found that chl a levels in water as far as $1000 \mathrm{~m}$ from fish cages were up to 25 times higher than at 5 control sites (Modica et al. 2006). However, all the chlorophyll levels measured were well below the eutrophication threshold for that area, and the researchers concluded that the organic enrichment from the farm was not likely to result in undesirable biological consequences. In the eastern Mediterranean, Pitta et al. (2005) analyzed sites near (2-3 nautical miles) and distant (20 nautical miles) from fish farms to determine whether nutrient enrichment from them caused large-scale effects on water quality and plankton assemblages. Chl a was significantly and consistently increased at the near sites, but significant seasonal and regional variability was also observed. The authors suggest that there was rapid utilization of nutrients by planktonic organisms, coupled with a transfer of nutrients up the food web without leaving behind significant traces of eutrophication. There was evidence of increased chl a production below the thermocline, suggesting that resuspension of nutrients, especially phosphorus, was an important process. Given the large area sampled, it appears nutrient flux out of these farms was evident at scales larger than in many other studies. Another study pointing to the capacity of aquaculture to impact water quality at regional scales demonstrated that increased nitrogen and phosphorus loading from 2000-2007 in a Sicilian Gulf could be attributed to the expansion of sea bream, sea bass and tuna farming aquaculture (Sarà et al. 2011). Up to $275 \mathrm{t}$ of these nutrients were added annually to the Gulf representing $17 \%$ of the nitrogen and $34 \%$ of the phosphorus regional inputs per year. Chl a concentrations tripled during this time, closely correlating with the increase in phosphorus. This is one of the few studies to detect impacts at regional spatial scales.

Carbon isotope analysis of seagrass and brown algae collected near the outfall of an Italian landbased fish farm and non-impacted control areas showed that plants closest to the outfall sequestered significantly more $\delta^{15} \mathrm{~N}$ associated with the farm effluent than occurred up to $2 \mathrm{~km}$ away (Vizzini et al. 2005). However, differences in the $\delta^{13} \mathrm{C}$ isotope signature were not as clearly evident. While this study was not conducted at a cage farm, it provided insight into nearshore nutrient processes and also provided information for a follow up study. Vizzini \& Mazzola (2006) used stable isotope ratios to compare the impact of anthropogenic organic matter from onshore and offshore fish farming and a sewage outfall on seagrass and 2 green algae. As in the previous study, $\delta^{15} \mathrm{~N}$ was the better tracer for nutrification, showing a distinct pattern of increased isotope uptake near the fish and sewage effluent sources compared to control sites 2 and $6 \mathrm{~km}$ away. The effluent isotope signature was also evident at higher trophic levels, indicating local nutrient assimilation. This methodology was not able to discriminate the exact anthropogenic source of enrichment in the sampled plants. Stable isotope signatures may be more evident with nitrogen than carbon in strongly oligotrophic systems where nitrogen is limited.

Apostolaki et al. (2007) found varying effects of effluent on chl $a$ at 3 Mediterranean sea bream and sea bass farms - only 1 farm showed increasing productivity, while the other 2 showed a negative influence or no effect. This suggests that the site-specific interplay of a variety of water column characteristics is important in determining ecological outcomes. A 3-dimensional model validation study in Greece suggested that increased nutrient effluents from fish farms did have the potential to increase chl a values leading to a more linear food chain (Tsagaraki et al. 2011). This hypothesis was supported by a concurrent field study conducted by the same research team, which sampled plankton community composition up and downstream of 4 sea bass and sea bream farms at 2 locations (Tsagaraki et al. 2013). There were no significant changes in chl a concentrations at either location attributed to farm effluent. However, there were significant shifts in the phytoplankton community composition at both locations. Species diversity upstream was lower (Margalef's diversity index value $=6.7)$ than downstream $(8.1-10.5)$ at one of the locations, likely due to nutrient enrichment, with community changes measurable $500 \mathrm{~m}$ downstream of farm cages.

A mesocosm study examined short-term nutrient and phytoplankton dynamics in a Chilean fjord to assess the potential impacts of nutrient loading from marine aquaculture (Iriarte et al. 2013). Phytoplankton response in terms of chl $a$, abundance and species composition to nitrogen loading was evident. The authors suggested that phytoplankton communities may be sensitive to nutrient loading in these fjords.

A water quality study in the South China Sea found that the highest chl a concentrations (average of $11.7 \mathrm{mg} \mathrm{m}^{-3}$ ) occurred in a semi-enclosed bay in an area where aquaculture cages were concentrated (Song et al. 2004). Values elsewhere in the bay were as low as $3.8 \mathrm{mg} \mathrm{m}^{-3}$. Industrial and urban pollution were also factors that contributed to nutrient enrichment and increased primary productivity in this bay. 
A later study in the same bay again found increased chl a concentrations in the fish farming zone which were attributed to nutrient discharge (Sun et al. 2011). Additionally, the phytoplankton community composition response differed with large diatoms in the dry season being replaced by smaller species in the wet season. Another study in China reported significant differences in phytoplankton around fish farms compared to shellfish and kelp farms (Jiang et al. 2012). Phytoplankton communities varied greatly in terms of abundance and species composition around the 3 types of farms and compared to samples from outside the farms, but interestingly the authors found no clear relationship between farm nutrient discharge and phytoplankton biomass. In Taiwan, Huang et al. (2011) found chl a levels ranging from 1.5-1.8 $\mu \mathrm{g} \mathrm{l}^{-1}$ in a semi-enclosed bay with well-established smallscale fish cage culture compared to 1.0-1.4 $\mathrm{\mu g} \mathrm{l}^{-1}$ at a nearby reference site. Macroalgae fouling on net pens at farm sites was 2-10 times higher than at reference locations, and nutrient concentrations were above eutrophication thresholds. Hydrological conditions and the use of unprocessed fish as feed were considered the main causative factors.

\section{Harmful algal blooms}

HABs are concentrated densities of phytoplankton that produce harmful effects in humans or marine life. Because of the potential harm to public health and fisheries, the possibility that marine fish farm effluent could induce HABs in coastal waters has been raised (Bouwman et al. 2013). When these occur near fish farms, fish may die as a direct result of poisoning, gill damage or decreased growth and vigor (Beveridge 2004, Davidson et al. 2009, Borg et al. 2011).

The current consensus is that little research to date has shown a link between nutrient discharge from fish farms and the occurrence of HABs (Nash 2001, Silvert 2001, Black et al. 2002, Cole 2002, Huntington et al. 2006, Halwart et al. 2007). Similar to other algae species, the nutrient fluxes that influence HAB population dynamics are complex and vary for different species (Anderson et al. 2002, 2008, Vargo 2009, Lewitus et al. 2012, Iriarte et al. 2013, Davidson et al. 2014). Environmental factors other than nutrient loading also contribute to the formation of HABs. For example, in the Pacific Northwest, coastal hydrogeology, light limitation of primary productivity and a well-mixed water column tend to minimize HABs near many salmon farming areas (Rensel et al. 2010).
There are few studies which indicate a direct link between HABs and aquaculture nutrient discharge. In a major aquaculture area in Guangdong province, China, the occurrence of algal blooms more than tripled from 1994-2004 compared to the previous decade (Yu et al. 2007). This included the occurrence of HABs near fish farms (Song et al. 2004, Liu et al. 2012), but industrial, agricultural and nuclear facilities in the same area also contributed heavily to eutrophication and warming of the waters in the semienclosed bay. Bodennec et al. (2002) found that exposure of ichthyotoxic algal species to dead fish and fish feed elutriates in the laboratory increased growth rates of the algal species and their toxicity to fish.

To avoid any potential negative interactionseither harm to the fish due to exposure or stimulation of HABs from aquaculture discharge-farms should not be sited in areas with historically recurring HABs, low water exchange rates or high nutrient loads required for toxic algal bloom formation (Nash 2003, Beveridge 2004, Nash et al. 2005, Borg et al. 2011).

\section{MANAGEMENT STRATEGIES TO MAINTAIN WATER QUALITY}

\section{Siting and farm operations}

Water quality impacts associated with marine fish cage culture in coastal waters and the open ocean may be avoided or ameliorated by careful siting and modern farm management. While fish farms may contribute to ocean eutrophication in some coastal areas, quantifying the nutrient budgets of open oceans is complex and there is a lack of inventory of contributing nutrient sources in most locations worldwide. Thus, questions remain about the singular risk that marine cage culture poses for water column enrichment and eutrophication at large scales (Olsen et al. 2008, IUCN 2009, Ross et al. 2013a). While results and impacts vary among farm sites and between species, there is agreement that there have been significant advances in the management of marine cage operations over the last twenty years, resulting in improved water quality near farms. Improvements in feed formulation and management are largely credited for reducing nitrogen and phosphorus loading and other water quality impacts observed in different areas (Stickney 2002, Braaten 2007, Pittenger et al. 2007, Belle \& Nash 2008, Olsen et al. 2008, Bureau \& Hua 2010). When best management practices include siting farms in areas with strong current (mean $>7 \mathrm{~cm}$ $\mathrm{s}^{-1}$ ) and with depth at least twice that of the net pens 
(Belle \& Nash 2008), nutrients will likely be diluted within a few hundred meters and dispersed for natural assimilation. However, Pittenger et al. (2007) caution that dilution is not a sufficient strategy to address the issue and recommend that proper siting is a primary factor in managing water quality impacts. Recent work to develop spatial decision support systems (SDSS) is providing innovative and interdisciplinary approaches to aid in siting farms (IUCN 2009, Kapetsky et al. 2013, Lovatelli et al. 2013, Ross et al. 2013b). Such tools are vitally important for coastal managers who must find balance between the many environmental, technological, economic and regulatory factors involved in site selection. Once farms are operational, adherence to best management practices, improved feed formulation and integrated multi-trophic aquaculture (IMTA)-farming species from different trophic levels together to promote the uptake of waste nutrients - will minimize impacts on water quality. Care must be taken to ensure that scaling up production in areas benefitting from improved feed management does not affect water quality.

Though there is some evidence that effluent from fish farms may result in increased primary productivity, it is more often the case that no direct causal relationship has been demonstrated. When effects are found, unfavorable hydrological conditions or poor farm management practices may contribute. It is uncommon for phytoplankton productivity and blooms, including harmful algae blooms, resulting from eutrophication to be attributed to fish farms. Nearshore farms should not be located in areas where effluent can wash onshore to avoid eutrophication in coastal waters (Robinson et al. 2005).

Because a change in primary productivity linked to fish farm effluents must be detected against the background of natural variability, it may be difficult to discern effects unless they are large (as high as a $50 \%$ increase) relative to this variation and of sufficient duration to be observed (Huntington et al. 2006). Many farms conduct routine water sampling as part of their regulatory requirements. Given the difficulty in attributing increased primary productivity directly to nutrient enrichment, it is suggested that sampling include direct measurements of chl $a$, or other metrics of productivity (Pittenger et al. 2007). Because nutrients may be flushed away from the immediate cage area and dispersed into the surrounding water body, it is difficult to assess whether farfield primary production is being affected over large areas and at longer time scales (Grant 2010). This is further complicated by the occurrence of many anthropogenically derived nutrients in coastal mar- ine waters, making it difficult to attribute nutrification to any one source, including aquaculture. Regional management strategies could benefit from long-term monitoring that includes analyses (e.g. stable isotope analysis) which may detect sources of nutrient loading such as fish farm waste.

\section{Integrated multi-trophic aquaculture}

IMTA is the culturing of fed finfish in combination with other species that filter waste particulates and dissolved nutrients, thereby reducing organic discharge and expanding the economic base of a farming operation (Chopin 2006). In addition to nutrient uptake benefits and production enhancement, IMTA may mitigate pathogens (Pang et al. 2006) and improve social acceptance of aquaculture if people believe it reduces negative impacts and increases sustainability (Barrington et al. 2010). Though largely experimental, the incorporation of IMTA into marine finfish aquaculture is identified as a best management practice (Stickney 2002, Belle \& Nash 2008, Johnson et al. 2008, Kalogerakis et al. 2014) and may be nearing commercial scales in the USA (Barrington et al. 2009). As the offshore marine aquaculture industry expands, demand for farm management protocols emphasizing sustainability will increase. IMTA offers a solution that could improve environmental quality while providing economic diversification. In fact, IMTA is the only remediation system with the potential to recoup implementation costs, as all other approaches incur costs without the potential for generating revenue (Troell et al. 2009). Thus, we include an extensive review of IMTA science and technology as management options for addressing water quality impacts at marine aquaculture operations.

Research at marine fish farms has demonstrated the potential benefits of IMTA with shellfish. Stirling \& Okumus (1995) found mussels Mytilus edulis cultured at Scottish salmon farms showed augmented growth compared to those grown at a nearby shellfish farm. A demonstration farm in the Gulf of Maine has successfully grown mussels near submersible Atlantic halibut Hippoglossus hippoglossus and haddock Melanogrammus aeglifinis cages (Langan 2004). In Maine, sea scallops Placopecten magellanicus cultured in suspension at salmon farms grew to sizes comparable to those grown at a nearby scallop aquaculture site (Parsons et al. 2002). A lab and field study in Canada found that mussels fed salmon feed and fecal particulates showed the same organic matter absorption efficiency as those consuming commercial bivalve feeds 
(Reid et al. 2010). A pilot project in the Bay of Fundy grew seaweed and mussels with salmon, and a social acceptability survey found an increased approval rating for IMTA compared to monoculture (Ridler et al. 2007). In the United Kingdom, Whitmarsh et al. (2006) concluded that mussels could remove a proportion of the organic waste produced by salmon farms while also offering financial benefits to the owner. A study in Italy (Sarà et al. 2009) tested the potential of integrating mussel culture at a sea bass and sea bream farm. Mussels grown downstream of fish cages showed greater growth after $1 \mathrm{yr}$ compared to those at control sites. It should be noted that implementing IMTA in the Mediterranean, or other predominantly oligotrophic waters, may be a challenge because the baseline productivity may be insufficient to support cultivation of filter-feeding organisms, even when farms are discharging nutrients (Angel \& Freeman 2009). Recent work on feeding behavior of mussels near salmon farms in the Bay of Fundy (MacDonald et al. 2011) and the use of stable isotopes to trace assimilation of fish feed in mussels (Redmond et al. 2010) indicate that shellfish can be successfully used to capture farm nutrients. Other invertebrates being considered for IMTA include spiny lobster Panulirus argus (Davis et al. 2006), sea cucumbers Parastichopus californicus (Ahlgren 1998) and sea urchins Paracentrotus lividus (Cook \& Kelly 2007).

There is also interest in developing IMTA capacity for seaweed culture. In Chile, Buschmann et al. (2009) estimated culturing 50-60 ha of algae downstream of a salmon farm would result in an $80 \%$ reduction of nitrogen entering the environment. The growth of Porphyra (nori) at salmon farms in the North Atlantic Ocean was compared to seaweed growing away from farm influence (Chopin et al. 1999). Seaweed tissue $N$ and $P$ levels varied with location and seawater nutrient concentrations, and growth varied by species and seasonally. Based upon mass balance modeling of nutrient release from Norwegian salmon farms, Wang et al. (2012) demonstrated a higher potential for seaweed production than for mussels.

Recent field studies and modeling investigated the potential of co-culturing blue mussels and brown algae Saccharina latissima with Atlantic salmon in Norway (Handå et al. 2012, 2013, Broch et al. 2013). Fatty acid profiles from the mussel tissue indicated that the organisms incorporated nutrients from salmon feed. Though seasonal differences in growth rates were observed between mussels grown at or away from fish farms, at the end of the annual growth cycle no differences in size were evident (Handå et al. 2012). In contrast, the brown algae sporophytes deployed $5 \mathrm{~m}$ below the surface at fish farms grew significantly larger than those at reference sites (Handå et al. 2013). Because of seasonal differences in growth, the best results were found for algae deployed in August and February. The ammonium concentrations at the fish farm and higher tissue nitrogen suggested that feed-derived nitrogen contributed to fertilization of the sporophytes. Deployment season and depth were also factors affecting algal growth rates which would need to be considered for large scale implementation. Broch et al. (2013) used a 3-dimensional model to estimate the full-scale harvest and nutrient uptake potential of macroalgal culture integrated at a salmon farm. They predicted yields of $75 \mathrm{t}$ brown algae per hectare over 4 mo from February to June and $175 \mathrm{tha}^{-1}$ over $10 \mathrm{mo}$ from August to June. The estimated nitrogen removal of 1 ha of algal production associated with $5000 \mathrm{t}$ salmon production was modest, ranging from $0.34-0.41 \%$ of inorganic nitrogen effluent. With macroalgal culture scaled up to a farm footprint of the same size and biomass yield as the salmon farm, they estimated $10 \%$ nitrogen removal. These studies highlight both the potential for integrating additional species into fish culture operations and also the research and technological development still needed to make the practice commercially viable.

The application of IMTA primarily as a filtration or remediation technique, rather than for food production, has been investigated (Chávez-Crooker \& Obreque-Contreras 2010). Chung et al. (2002) evaluated several species of seaweed in Korea and determined Porphyra and Ulva had up to 6 times higher rates of short term ammonia uptake than other algal species analyzed. In Japan 3 species of seaweeds were cultured year-round at fish farms to calculate nitrogen and phosphorus uptake, oxygen production and growth rates to improve water quality (Kitadai \& Kadowaki 2007). Growth rates up to $4.2 \mathrm{~cm} \mathrm{~d}^{-1}$ were reported and oxygen production was 8-11 times higher than consumption. Nitrogen and phosphorus uptake were $2.9-3.6 \mathrm{mg} \mathrm{m}^{-2} \mathrm{~d}^{-1}$ and $0.19-0.54 \mathrm{mg}$ $\mathrm{m}^{-2} \mathrm{~d}^{-1}$, respectively. A similar effort was made in sea bass and croaker farms and macroalgae culture areas in Nansha Bay, China (Jiang et al. 2010). The authors calculated that for each fish cage, $450 \mathrm{~m}^{2}$ of Laminaria and $690 \mathrm{~m}^{2}$ of Gracilaria were required to maintain water quality and prevent eutrophication. At an intensive sea bream growout farm, Ulva and Gracilaria tanks were added to treat the farm effluent and remove nitrogen and phosphorus (Hernandez et al. 2005). The Ulva removed $8.9 \%$ of the phosphorus 
input and $24 \%$ of nitrogen. The Gracilaria removed $3.2 \%$ of the phosphorus and $19 \%$ of the nitrogen input. Heavy metal analysis of the seaweeds determined there was no contamination, thereby making the tissues suitable for use in the food industry. Species of Porphyra from Asia and the USA have also been tested in the laboratory by Kraemer et al. (2004) and appear to be an excellent choice for commercial and bioremediation applications based upon nutrient uptake rates. Lab experiments in Korea with Codium suggest it may be useful for IMTA in fish farming areas with high water temperatures (Kang et al. 2008).

Mathematical models designed to predict waste dispersion and carrying capacity relative to multispecies invertebrate mariculture (Duarte et al. 2003, Reid et al. 2009, 2011) will be useful in designing IMTA systems that balance the nutrient inputs of the finfish with optimized culture of filtering organisms. Recent modeling by Sarà et al. (2012) predicted that mussels Mytilus galloprovincialis and oysters Crassostrea gigas grown around fish cages in the Mediterranean would exhibit greater growth (nearly doubled for oysters) in water enriched by farm effluent, compared to sites away from cages. Predictions correlated well with previous field experiment results. Development of advanced models to integrate IMTA into nutrient discharge models will be especially relevant in areas with high fish production demands and moderate flushing capacity to help manage nutrient inputs by harnessing the assimilative capacity of IMTA biofiltering components. For seaweed culture, open ocean harvesting techniques and estimating the capacity to remove nutrients in an open water system are 2 areas requiring further work. There is still only limited knowledge about seaweeds that may be useful for marine finfish IMTA endeavors; such as species of Ulva, Porphyra, Gracilaria and Laminaria (Neori et al. 2004).

Though the remoteness and high energy environment of the open ocean pose great challenges to IMTA implementation, engineering commercially viable IMTA systems has gained momentum in the past decade (Troell et al. 2009, Chopin et al. 2013). There is great interest in pursuing the expansion of IMTA to marine cage culture, and successful pilot projects indicate that it is feasible (Blouin et al. 2007, Robinson et al. 2011). As this industry expands globally, continued research and development efforts to identify the right species and technologies for co-culture will advance IMTA from an experimental to a profitable aspect of sustainable marine fish aquaculture.

\section{LOOKING FORWARD}

The joint objectives of economically and ecologically sustainable marine aquaculture are possible when optimal siting and best management practices are implemented, if monitoring protocols are in place for early detection of impacts, and if technological innovations continue to offer advanced solutions to the challenges of the open ocean. As evidenced by much of the research we reviewed, modern operating conditions have minimized impacts of individual fish farms on marine water quality (Table 6). Effects on dissolved oxygen and turbidity have been largely eliminated through better management. Near-field nutrient enrichment to the water column is usually not detectable beyond $100 \mathrm{~m}$ of the farm when formulated feeds are used, feed waste is minimized and farms are properly sited in deep waters with flushing currents. The trend toward moving industrial-scale aquaculture into offshore waters is increasingly feasible as cage and farm structure technology emerges to withstand the harsh conditions of the open ocean (Holmer 2010). When sited nearshore, extra caution should be taken to manage farm location, size, biomass, feeding protocols, orientation with respect to prevailing currents and water depth to minimize near- and far-field impacts.

Regardless of location, other environmental risks may still face this industry. Significant questions remain about the additive impacts of discharge from multiple, proximal farms, potentially leading to increased primary production and eutrophication. Research results on secondary effects to primary production resulting from nutrification are highly variable. In some locations, increased nutrient loading has little or no trophic impacts, while at other farms there is evidence that nutrients are assimilated by primary producers. This increase in primary production may be interpreted as harmful and indicative of a shift to eutrophic conditions, but other researchers see the farms providing a net benefit by enhancing production in nutrient-limited systems. The ecological mechanisms explaining this variability in trophic transfer of energy from fish farms to the marine food web will require further investigation.

Research to shed light on far-field and regional processes, especially in intensively farmed areas and over longer time scales, must continue. As more and more human activities, including aquaculture, expand and extend further offshore, it is increasingly difficult to assess the cumulative effects on marine ecosystems (Clarke Murray et al. 2014). Future research efforts should focus on effective monitoring 
Table 6. Summary of environmental impacts of marine fish farms on water quality parameters at multiple scales

\begin{tabular}{|c|c|c|c|c|}
\hline $\begin{array}{l}\text { Environmental } \\
\text { impact }\end{array}$ & Near-field detection & Far-field detection & $\begin{array}{l}\text { Detection of cumulative } \\
\text { impacts of multiple farms }\end{array}$ & $\begin{array}{l}\text { Drivers and targets for } \\
\text { farm management }\end{array}$ \\
\hline $\begin{array}{l}\text { Increased dissolved } \\
\text { nitrogen and } \\
\text { phosphorus }\end{array}$ & $\begin{array}{l}\text { None to moderate; } \\
\text { usually confined to } \\
<100 \text { m from fish } \\
\text { farm }\end{array}$ & None to small & $\begin{array}{l}\text { None to very small } \\
\text { Difficult to attribute to } \\
\text { fish farms }\end{array}$ & $\begin{array}{l}\text { Feed type } \\
\text { Species cultured } \\
\text { Feed management } \\
\text { Depth } \\
\text { Hydrology }\end{array}$ \\
\hline Increased turbidity & $\begin{array}{l}\text { None to small; confined } \\
\text { to immediate cage area }\end{array}$ & None to very small & None & $\begin{array}{l}\text { Feed type } \\
\text { Feed composition } \\
\text { Current }\end{array}$ \\
\hline
\end{tabular}

and assessment methods that increase our ability to detect aquaculture effects at far-field scales, to assess those effects in relation to other natural and anthropogenic factors impacting ocean condition, and to manage farms responsibly and sustainably within an ecological framework.

It is of utmost importance to consider the trophic status and background nutrient flux of the receiving water, as well as other sources of nutrient loading, when assessing the relative contribution of marine fish farm discharge to the environment. Because nutrients tend to get flushed away from the farm area faster than they can be assimilated into the food web, it is difficult to measure direct impacts on phytoplankton production. Continued research to understand and model the complex array of forces driving nutrient dispersion in and around fish farms, including bathymetry, current flow, tidal fluctuation, and Earth's rotation (Kalantzi \& Karakassis 2006, Karney \& Venayagamoorthy 2013), will provide additional tools to develop sustainable farming practices. Few comparative analyses have investigated correlations between farm sites (e.g. depth, latitude, current profile), management characteristics (e.g. species cultured, volume of cages, biomass, feeding rate) and measured water quality impacts (Sarà 2007) over repeated production cycles, so additional research in this area would be beneficial. Such analyses are particularly challenging as these variables are neither consistently monitored nor reported in published formats, and the parameter units are not standardized. Multivariate statistical analysis of studies such as those in Tables 2, 4 \& 5 would provide valuable quantitative insights into the complex interplay of farm location, operational standards, production parameters, water quality, and primary production, thus providing a more thorough understanding of the ecological role of aquaculture in the marine environment.

The human population will continue to increase and harvesting of wild fisheries stocks will not be able to satisfy the demand for seafood (Handisyde et al. 2006, Duarte et al. 2009). Aquaculture provides a valuable and reliable source of protein and already produces about half of the fish protein consumed by humans (FAO 2012, Subasinghe et al. 2012). Terrestrial farming is predicted to be impacted by climate change and coastal communities will need to develop effective response measures (Callaway et al. 2012, Merino et al. 2012). Marine aquaculture has great potential to be an integral part of climate adaptation strategies, in terms of both food and job security (De Silva \& Soto 2009), because it can provide alternative livelihood means to current farming that may not be possible due to changes in precipitation, saltwater intrusion, or flooding. As this industry expands in the coming decades, it is imperative that we continue to examine the potential risks and benefits of aquaculture in the marine environment.

Acknowledgements. This work was financially supported by the NOAA Fisheries Office of Aquaculture and the NOAA National Centers for Coastal Ocean Science. We thank our expert colleagues and the anonymous reviewers whose valuable contributions improved the manuscript. 


\section{LITERATURE CITED}

á Norði G, Glud RN, Gaard E, Simonsen K (2011) Environmental impacts of coastal fish farming: carbon and nitrogen budgets for trout farming in Kaldbaksfjørður (Faroe Islands). Mar Ecol Prog Ser 431:223-241

> Aguado-Giménez F, García-García B, Hernández-Lorente MD, Cerezo-Valverde J (2006) Gross metabolic waste output estimates using a nutritional approach in Atlantic bluefin tuna (Thunnus thynnus) under intensive fattening conditions in western Mediterranean Sea. Aquacult Res 37:1254-1258

- Ahlgren MO (1998) Consumption and assimilation of salmon net pen fouling debris by the Red Sea cucumber Parastichopus californicus: implications for polyculture. J World Aquacult Soc 29:133-139

Aksu M, Kocatas A (2007) Environmental effects of the three fish farms in Izmir Bay (Aegean Sea, Turkey) on water column and sediment. Rapp Comm Int Mer Mediterranee 38:414

Aksu M, Kaymakci-Basaran A, Egemen O (2010) Long-term monitoring of the impact of a capture-based bluefin tuna aquaculture on water column nutrient levels in the Eastern Aegean Sea, Turkey. Environ Monit Assess 171: 681-688

Alston DE, Cabarcas A, Capella J, Benetti DD, KeeneMeltzoff S, Bonilla J, Cortes R (2005) Environmental and social impacts of sustainable offshore cage culture production in Puerto Rican waters. Final report to the National Oceanic and Atmospheric Administration, Contract NA16RG1611. Available at www.lib.noaa.gov/ retiredsites/docaqua/reports_noaaresearch/finaloffshore puertorico.pdf (accessed 27 Sept 2012)

> Anderson DM, Glibert PM, Burkholder JM (2002) Harmful algal blooms and eutrophication: nutrient sources, composition, and consequences. Estuaries 25:704-726

Anderson DM, Burkholder JM, Cochlan WP, Glibert PM and others (2008) Harmful algal blooms and eutrophication: examining linkages from selected coastal regions of the United States. Harmful Algae 8:39-53

Angel D, Freeman S (2009) Integrated aquaculture (INTAQ) as a tool for an ecosystem approach to the marine farming sector in the Mediterranean Sea. In: Soto D (ed) Integrated mariculture: a global review. FAO Fish Aquacult Tech Pap 529. FAO, Rome, p 133-183. Available at ftp: //ftp.fao.org/docrep/fao/012/i1092e/i1092e04a.pdf (accessed 1 Oct 2012)

Apostolaki ET, Tsagaraki T, Tsapaki M, Karakassis I (2007) Fish farming impact on sediments and macrofauna associated with seagrass meadows in the Mediterranean. Estuar Coast Shelf Sci 75:408-416

Barrington K, Chopin T, Robinson S (2009) Integrated multitrophic aquaculture (IMTA) in marine temperate waters. In: Soto D (ed) Integrated mariculture: a global review. FAO Fish Aquacult Tech Pap 529. FAO, Rome, p 7-46. Available at ftp://ftp.fao.org/docrep/fao/012/ i1092e/i1092e02a.pdf (accessed 1 Oct 2012)

Barrington K, Ridler N, Chopin T, Robinson S, Robinson B (2010) Social aspects of the sustainability of integrated multi-trophic aquaculture. Aquacult Int 18:201-211

Basaran AK, Aksu M, Egemen O (2007) Monitoring the impacts of the offshore cage fish farm on water quality located in Ildir Bay (Izmir-Aegean Sea). Tarim Bilim Derg 13:22-28 (in Turkish with English abstract)

Basaran AK, Aksu M, Egemen O (2010) Impacts of the fish farms on the water column nutrient concentrations and accumulation of heavy metals in the sediments in the eastern Aegean Sea (Turkey). Environ Monit Assess 162: 439-451

Belias CV, Bikas VG, Dassenakis MJ, Scoullos MJ (2003) Environmental impacts of coastal aquaculture in eastern Mediterranean bays: the case of Astakos Gulf, Greece. Environ Sci Pollut Res Int 10:287-295

Belle SM, Nash CE (2008) Better management practices for net-pen aquaculture. In: Tucker CS, Hargreaves JA (eds) Environmental best management practices for aquaculture. Blackwell Publishing, Ames, IA, p 261-330

Benetti D, Brand L, Collins J, Brooks G and others (2005) Final report on Cape Eleuthra offshore aquaculture project. Cape Eleuthra Institute and AquaSense LLC, Bahamas

Benetti DD, O'Hanlon B, Rivera J, Welch A, Maxey C, Orhun MR (2010) Growth rates of cobia (Rachycentron canadum) cultured in open ocean submerged cages in the Caribbean. Aquaculture 302:195-201

Beveridge M (2004) Cage aquaculture. Blackwell Publishing, Oxford

Black KD, Cook EJ, Jones KJ, Kelly MS and others (2002) Review and synthesis of the environmental impacts of aquaculture. Scottish Association for Marine Science and Napier University, Scottish Executive Central Research Unit, Edinburgh. Available at www.scotland.gov.uk/ Publications/2002/08/15170/9405 (accessed 1 Oct 2012)

Blouin N, Xiugeng F, Peng J, Yarish C, Brawley SH (2007) Seeding nets with neutral spores of the red alga Porphyra umbilicalis (L.) Kützing for use in integrated multitrophic aquaculture (IMTA). Aquaculture 270:77-91

Bodennec G, Arzul G, Crassous MP, Youenou A (2002) Influence of dead fish and uneaten fish feed elutriates on the toxic potential of certain microalgae. IFREMER Actes Colloq 34:145-156

Borg JA, Crosetti D, Massa F (eds) (2011) Site selection and carrying capacity in Mediterranean marine aquaculture: key issues. Draft Report GFCM:XXXV/2011/Dma.9. General Fisheries Commission for the Mediterranean, 35th Session, 9-14 May 2011, Rome, Italy. Available at http://151.1.154.86/GfcmWebSite/GFCM/35/GFCM_ XXXV_2011_Dma.9.pdf (accessed 1 Oct 2012)

Bouwman L, Beusen A, Glibert PM, Overbeek C and others (2013) Mariculture: significant and expanding cause of coastal nutrient enrichment. Environ Res Lett 8:044026

Braaten B (2007) Cage culture and environmental impacts. In: Bergheim A (ed) Aquacultural engineering and environment. Research Signpost, Kerala, p 49-91

Broch OJ, Ellingsen IH, Forbord S, Wang X and others (2013) Modelling the cultivation and bioremediation potential of the kelp Saccharina latissima in close proximity to an exposed salmon farm in Norway. Aquacult Environ Interact 4:187-206

Brooks KM, Mahnken CVW (2003) Interactions of Atlantic salmon in the Pacific Northwest environment. III. Accumulation of zinc and copper. Fish Res 62:295-305

Bureau DP, Hua K (2010) Towards effective nutritional management of waste outputs in aquaculture, with particular reference to salmonid aquaculture operations. Aquacult Res 41:777-792

Buschmann A, Costa-Pierce BA, Cross S, Iriarte JL, Olsen YO, Reid G (2007) Nutrient impacts of farmed Atlantic salmon (Salmo salar) on pelagic ecosystems and implications for carrying capacity. Report of the Technical Working Group on Nutrients and Carrying Capacity of the World Wildlife Fund Salmon Aquaculture Dialogue. World Wildlife Federation, Washington, DC

Buschmann AH, Cabello F, Young K, Carvajal J, Varela DA, 
Henriquez L (2009) Salmon aquaculture and coastal ecosystem health in Chile: analysis of regulations, environmental impacts and bioremediation systems. Ocean Coast Manag 52:243-249

> Callaway R, Shinn AP, Grenfell SE, Bron JE and others (2012) Review of climate change impacts on marine aquaculture in the UK and Ireland. Aquat Conserv Mar Freshw Ecosyst 22:389-421

> Chávez-Crooker P, Obreque-Contreras J (2010) Bioremediation of aquaculture wastes. Curr Opin Biotechnol 21: 313-317

Chopin T (2006) Integrated multi-trophic aquaculture. What it is and why you should care and don't confuse it with polyculture. North Aquacult 12:4

Chopin T, Yarish C, Wilkes R, Belyea E, Lu S, Mathieson A (1999) Developing Porphyra/salmon integrated aquaculture for bioremediation and diversification of the aquaculture industry. J Appl Phycol 11:463-472

Chopin T, Robinson S, Reid G, Ridler N (2013) Prospects for integrated multi-trophic aquaculture (IMTA) in the open ocean. Bull Aquacult Assoc Canada 11:28-35

> Chung IK, Kang YH, Yarish C, Kraemer GP, Lee JA (2002) Application of seaweed cultivation to the bioremediation of nutrient-rich effluent. Algae 17:1-10

Clarke Murray C, Mach ME, Martone RG (2014) Cumulative effects in marine ecosystems: scientific perspectives on its challenges and solutions. World Wildlife Federation Canada, Vancouver and Center for Ocean Solutions, Monterey, CA

> Cloern JE (2001) Our evolving conceptual model of the coastal eutrophication problem. Mar Ecol Prog Ser 210: 223-253

Cole R (2002) Impacts of marine farming on wild fish populations. Final Research Report for Ministry of Fisheries Research Project ENV2000/08, Objective One. National Institute of Water and Atmospheric Research, Auckland

Cook EJ, Kelly MS (2007) Enhanced production of the sea urchin Paracentrotus lividus in integrated open-water cultivation with Atlantic salmon Salmo salar. Aquaculture 273:573-585

> Dalsgaard T, Krause-Jensen D (2006) Monitoring nutrient release from fish farms with macroalgal and phytoplankton bioassays. Aquaculture 256:302-310

Davidson K, Miller P, Wilding TA, Shutler J, Bresnan E, Kennington K, Swan S (2009) A large and prolonged bloom of Karenia mikimotoi in Scottish waters in 2006. Harmful Algae 8:349-361

Davidson K, Gowen RJ, Harrison PJ, Fleming LE, Hoagland P, Moschonas G (2014) Anthropogenic nutrients and harmful algae in coastal waters. J Environ Manag 146: 206-216

Davis M, O'Hanlon B, Rivera J, Corsaut J and others (2006) Recruitment of spiny lobsters, Panulirus argus, to submerged sea cages off Puerto Rico, and its implication for the development of an aquaculture operation. Proc Gulf Caribb Fish Inst 57:975-980

De Silva SS, Soto D (2009) Climate change and aquaculture: potential impacts, adaptation and mitigation. FAO Fish Aquacult Tech Pap 530. FAO, Rome

Demirak A, Balci A, Tufekci M (2006) Environmental impact of the marine aquaculture in Gulluk Bay, Turkey. Environ Monit Assess 123:1-12

> Dempster T, Korsoen O, Folkedal O, Juell JE, Oppedal F (2009) Submergence of Atlantic salmon (Salmo salar L.) in commercial scale sea-cages: a potential short-term solution to poor surface conditions. Aquaculture 288: 254-263
Doglioli AM, Magaldi MG, Vezzulli L, Tucci S (2004) Development of a numerical model to study the dispersion of wastes coming from a marine fish farm in the Ligurian Sea (western Mediterranean). Aquaculture 231:215-235

Duarte P, Meneses R, Hawkins AJS, Zhu M, Fang J, Grant J (2003) Mathematical modelling to assess the carrying capacity for multi-species culture within coastal waters. Ecol Modell 168:109-143

Duarte CM, Holmer M, Olsen Y, Soto D and others (2009) Will the oceans help feed humanity? BioScience 59:967-976

> Endo A, Srithongouthai S, Nashiki H, Teshiba I, Iwasaki T, Hama D, Tsutsumi H (2008) DO-increasing effects of a microscopic bubble generating system in a fish farm. Mar Pollut Bull 57:78-85

FAO (Food and Agriculture Organization of the United Nations) (2012) The state of the world fisheries and aquaculture 2010. FAO, Rome. Available at www.fao.org/ docrep/016/i2727e/i2727e00.htm (accessed 10 Jan 2012)

Galloway JN, Dentener FJ, Capone DG, Boyer EW and others (2004) Nitrogen cycles: past, present, and future. Biogeochemistry 70:153-226

Gillibrand PA, Cromey CJ, Black KD, Inall ME, Gontarek SJ (2006) Identifying the risk of deoxygenation in Scottish sea lochs with isolated deep water. A report to the Scottish Aquaculture Research Forum. Scottish Association for Marine Science, Oban. Available at www.sarf.org.uk/ cms-assets/documents/28798-260528.sarf017-final-reportrev-may2007.pdf. (accessed 27 Sept 2012)

> Goldburg R, Naylor R (2005) Future seascapes, fishing, and fish farming. Front Ecol Environ 3:21-28

Goldburg R, Triplett T (1997) Murky waters: environmental effects of aquaculture in the United States. Environmental Defense Fund, Washington, DC

Goldburg RJ, Elliott MS, Naylor RL (2001) Marine aquaculture in the United States: environmental impacts and policy options. Pew Oceans Commission, Arlington, VA

Grant J (2010) Coastal communities, participatory research, and far-field effects of aquaculture. Aquacult Environ Interact 1:85-93

> Grigorakis K, Rigos G (2011) Aquaculture effects on environmental and public welfare-the case of Mediterranean mariculture. Chemosphere 85:899-919

Grøttum JA, Beveridge M (2007) A review of cage aquaculture: northern Europe. In: Halwart M, Soto D, Arthur JR (eds) Cage aquaculture: regional reviews and global overview. FAO Fish Tech Pap 498. FAO, Rome, p 126-154. Available at www.fao.org/docrep/010/a1290e/ a1290e00.htm (accessed 29 Mar 2013)

Halwart M, Soto D, Arthur JR (eds)(2007) Cage aquaculture: regional reviews and global overview. FAO Fish Tech Pap 498. FAO, Rome. Available at ftp.fao.org/docrep/ fao/010/a1290e/a1290e.pdf (accessed 27 Sept 2012)

Handå A, Min H, Wang X, Broch OJ, Reitan KI, Reinertsen H, Olsen Y (2012) Incorporation of fish feed and growth of blue mussels (Mytilus edulis) in close proximity to salmon (Salmo salar) aquaculture: implications for integrated multi-trophic aquaculture in Norwegian coastal waters. Aquaculture 356-357:328-341

> Handå A, Forbord S, Wang X, Broch OJ and others (2013) Seasonal- and depth-dependent growth of cultivated kelp (Saccharina latissima) in close proximity to salmon (Salmo salar) aquaculture in Norway. Aquaculture 414415:191-201

Handisyde NT, Ross LG, Badjeck MC, Allison EH (2006) The effects of climate change on world aquaculture: a global perspective. Final Tech Rep, Institute of Aquaculture, Stirling 
Hargrave BT (2003) Far-field environmental effects of marine finfish aquaculture. Can Tech Rep Fish Aquat Sci 2450, Vol 1. DFO, Ottawa. Available at http://mmc.gov/ drakes_estero/pdfs/bivalve_aquaculture_03.pdf (accessed 27 Sept 2012)

Hargrave BT (2005) Environmental effects of marine finfish aquaculture. Handbook of environmental chemistry, Vol 5M. Springer-Verlag, Berlin

Harrison WG, Perry T, Li WKW (2005) Ecosystem indicators of water quality, Part I. Plankton biomass, primary production and nutrient demand. In: Hargrave BT (ed) Environmental effects of marine finfish aquaculture. Handbook of environmental chemistry, Vol 5M. SpringerVerlag, Berlin, p 59-82

Heath MR, Edwards AC, Patsch J, Turrell WR (2003) Application of the European Regional Seas Ecosystem Model (ERSEM) to assessing the eutrophication status in the OSPAR Maritime Area, with particular reference to nutrient discharges from Scottish salmonid aquaculture. OSPAR Environmental Assessment and Monitoring Committee (ASMO), London. Available at http://strathprints.strath.ac.uk/18590/ (accessed 2 Oct 2012)

Helsley CE (2007) Environmental observations around offshore cages in Hawaii. In: Lee CS, O'Bryen PJ (eds) Open ocean aquaculture-moving forward. Oceanic Institute, Waimanalo, HI, p 41-44. Available at nsgl.gso. uri.edu/ocei/oceiw06001.pdf (accessed 1 Oct 2012)

Hernandez I, Fernandez-Engo MA, Perez-Llorens JL, Vergara JJ (2005) Integrated outdoor culture of two estuarine macroalgae as biofilters for dissolved nutrients from Sparus auratus waste waters. J Appl Phycol 17:557-567

Holmer M (2010) Environmental issues of fish farming in offshore waters: perspectives, concerns, and research needs. Aquacult Environ Interact 1:57-70

Holmer M, Hansen PK, Karakassis I, Borg JA, Schembri P (2008) Monitoring of environmental impacts of marine aquaculture. In: Holmer M, Black K, Duarte CM, Marba N, Karakassis I (eds) Aquaculture in the ecosystem. Springer, Dordrecht, p 47-85

> Honkanen T, Helminen H (2000) Impacts of fish farming on eutrophication: comparisons among different characteristics of ecosystem. Int Rev Hydrobiol 85:673-686

> Huang YCA, Hsieh HJ, Huang SC, Meng PJ and others (2011) Nutrient enrichment caused by marine cage culture and its influence on subtropical coral communities in turbid waters. Mar Ecol Prog Ser 423:83-93

Hung JJ, Hung CS, Su HM (2008) Biogeochemical response to the removal of maricultural structures from an eutrophic lagoon (Tapong Bay) in Taiwan. Mar Environ Res 65:1-17

Huntington TC, Roberts H, Cousins N, Pitta V and others (2006) Some aspects of the environmental impact of aquaculture in sensitive areas. Final report to the Directorate-General Fish and Maritime Affairs of the European Commission. Poseidon Aquatic Resource Management Ltd., Lymington. Available at ec.europa.eu/fisheries/ documentation/studies/aquaculture_environment_2006_ en.pdf (accessed 27 Sept 2012)

Husa V, Kutti T, Ervik A, Sjøtun K, Hansen PK, Aure J (2014) Regional impact from fin-fish farming in an intensive production area (Hardangerfjord, Norway). Mar Biol Res 10:241-252

ICES (International Council for the Exploration of the Seas) (2002) Report of the working group on environmental interactions of mariculture. ICES CM 2002/F:04. ICES, Copenhagen. Available at www.ices.dk/sites/pub/ Publication Reports/Expert Group Report/mcc/2002/ wgeim02.pdf (accessed 28 Sept 2012)
IUCN (International Union for Conservation of Nature) (2007) Guide for the sustainable development of Mediterranean aquaculture. Interaction between aquaculture and the environment. IUCN, Gland. Available at cmsdata.iucn.org/downloads/acua_en_final.pdf (accessed 27 Sept 2012)

IUCN (2009) Aquaculture site selection and site management. IUCN, Gland

Iriarte JL, Pantoja S, Gonzalez HE, Silva G and others (2013) Assessing the micro-phytoplankton response to nitrate in Comau Fjord $\left(42^{\circ} \mathrm{S}\right)$ in Patagonia (Chile), using a microcosms approach. Environ Monit Assess 185:5055-5070

> Islam MS (2005) Nitrogen and phosphorus budget in coastal and marine cage aquaculture and impacts of effluent loading on ecosystem: review and analysis towards model development. Mar Pollut Bull 50:48-61

Jiang ZJ, Fang JG, Mao YZ, Wang W (2010) Eutrophication assessment and bioremediation strategy in a marine fish cage culture area in Nansha Bay, China. J Appl Phycol 22:421-426

Jiang ZB, Chen QZ, Zeng JN, Liao YB, Shou L, Liu J (2012) Phytoplankton community distribution in relation to environmental parameters in three aquaculture systems in a Chinese subtropical eutrophic bay. Mar Ecol Prog Ser 446:73-89

Johnson MR, Boelke C, Chiarella LA, Colosi P and others (2008) Impacts to marine fisheries habitat from nonfishing activities in the northeastern United States. NOAA Tech Memo NMFS-NE-209. US Dept of Commerce, NOAA, Gloucester, MA. Available at www.nefsc.noaa. gov/publications/tm/tm209/index.html (accessed 28 Sept 2012)

Kalantzi I, Karakassis L (2006) Benthic impacts of fish farming: meta-analysis of community and geochemical data. Mar Pollut Bull 52:484-493

Kalogerakis N, Arff J, Banat IM, Broch OJ and others (2014) The role of environmental biotechnology in exploring, exploiting, monitoring, preserving, protecting and decontaminating the marine environment. New Biotechnol 32:157-167

Kang YH, Shin JA, Kim MS, Chung IK (2008) A preliminary study of the bioremediation potential of Codium fragile applied to seaweed integrated multi-trophic aquaculture (IMTA) during the summer. J Appl Phycol 20: 183-190

Kapetsky JM, Aguilar-Manjarrez J, Jenness J (2013) A global assessment of offshore mariculture potential from a spatial perspective. FAO Fish Aquacult Tech Pap 549. FAO, Rome

Karney B, Venayagamoorthy SK (2013) Sustainability implications. In: Fernando HJS (ed) Handbook of environmental fluid dynamics: overview and fundamentals. CRC Press, Boca Raton, FL, p 53-62

Karydis M, Kitsiou D (2012) Eutrophication and environmental policy in the Mediterranean Sea: a review. Environ Monit Assess 184:4931-4984

Kitadai Y, Kadowaki S (2007) Growth, nitrogen and phosphorous uptake rates and $\mathrm{O}_{2}$ production rate of seaweeds cultured on coastal fish farms. Bull Fish Res Agency 19: 149-154

Klaoudatos SD (2000) Environmental impacts of aquaculture in Greece. Practical experiences. In: Uriarte A, Basurco B (eds) Environmental impact assessment of Mediterranean aquaculture farms. Cahiers Options Méditerranéennes 55. CIHEAM, Zaragoza, p 109-127. Available at http://ressources.ciheam.org/om/pdf/c55/01600226.pdf (accessed 1 Oct 2012) 
Kraemer GP, Carmona R, Neefus C, Chopin T, Miller S, Tang X, Yarish C (2004) Preliminary examination of the bioremediation and mariculture potential of a Northeast U.S.A. and Asian species of Porphyra. Bull Fish Res Agency (Suppl 1):77-82

Langan R (2004) Balancing marine aquaculture inputs and extraction: combined culture of finfish and bivalve molluscs in the open ocean. Bull Fish Res Agency (Suppl 1):51-58

Lewitus AJ, Horner RA, Caron DA, Garcia-Mendoza E and others (2012) Harmful algal blooms along the North American west coast region: history, trends, causes, and impacts. Harmful Algae 19:133-159

Liu H, Song X, Huang L, Tan Y, Zhong Y, Huang JR (2012) Potential risk of Mesodinium rubrum bloom in aquaculture area of Dapeng'ao cove, China: diurnal changes in the ciliate community structure in the surface water. Oceanologia 54:109-117

Loucks RH, Smith RE, Fisher CV, Fisher EB (2012) Copper in the sediment and sea surface microlayer near a fallowed, open-net fish farm. Mar Pollut Bull 64:1970-1973

Lovatelli A, Aguilar-Manjarrez J, Soto D (eds) (2013) Expanding mariculture farther offshore: technical, environmental, spatial and governance challenges. FAO Technical Workshop, 22-25 March 2010, Orbetello, Italy. FAO Fish Aquacult Proc 24. FAO, Rome

MacDonald BA, Robinson SMC, Barrington KA (2011) Feeding activity of mussels (Mytilus edulis) held in the field at an integrated multi-trophic aquaculture (IMTA) site (Salmo salar) and exposed to fish food in the laboratory. Aquaculture 314:244-251

Maldonado M, Carmona MC, Echeverria Y, Riesgo A (2005) The environmental impact of Mediterranean cage fish farms at semi-exposed locations: Does it need a reassessment? Helgol Mar Res 59:121-135

Mantzavrakos E, Kornaros M, Lyberatos G, Kaspiris P (2005) Impacts of a marine fish farm in Argolikos Gulf on the water column and the sediment. In: Proc 9th Int Conf Environ Sci Tech, Rhodes Island, Greece, 1-3 September 2005, p A928-933. Available at www.srcosmos.gr/ srcosmos/showpub.aspx?aa=6625 (accessed 1 Oct 2012)

Matijevic S, Kuspilic G, Morovic M, Grbec B, Bogner D, Skejic S, Veza J (2009) Physical and chemical properties of the water column and sediments at sea bass/sea bream farm in the middle Adriatic (Maslinova Bay). Acta Adriat 50:59-76

McKinnon D, Trott L, Duggan S, Brinkman R, Alongi D, Castine S, Patel F (2008) Environmental impacts of sea cage aquaculture in a Queensland context-Hinchinbrook Channel case study (SD576/06) final report. Australian Institute of Marine Science, Townsville. Available at www. aims.gov.au/c/document_library/get_file? uuid=965f17c9b42b-4e41-a5a5-e568a37a5459\&groupId=30301 (accessed 27 Sept 2012)

> Merino G, Barange M, Blanchard JL, Harle J and others (2012) Can marine fisheries and aquaculture meet fish demand from a growing human population in a changing climate? Glob Environ Change 22:795-806

Modica A, Scilipoti D, La Torre R, Manganaro A, Sara G (2006) The effect of mariculture facilities on biochemical features of suspended organic matter (southern Tyrrhenian, Mediterranean). Estuar Coast Shelf Sci 66:177-184

MSC (The Mediterranean Science Commission) (2007) Impact of mariculture on coastal ecosystems. CIESM Workshop Monographs No. 32, CIESM, Monaco. Available at www.ciesm.org/online/monographs/lisboa07.pdf (accessed 27 Sept 2012)

Nash CE (ed) (2001) The net-pen salmon farming industry in the Pacific Northwest. NOAA Tech Memo NMFSNWFSC-49. US Dept of Commerce, NOAA, Seattle, WA. Available at www.nwfsc.noaa.gov/publications/ techmemos/tm49/tm49.htm (accessed 27 Sept 2012)

$>$ Nash CE (2003) Interactions of Atlantic salmon in the Pacific Northwest. VI. A synopsis of the risk and uncertainty. Fish Res 62:339-347

Nash CE, Burbridge PR, Volkman JK (2005) Guidelines for ecological risk assessment of marine fish aquaculture. NOAA Tech Memo NMFS-NWFSC-71. US Dept of Commerce, NOAA, Seattle, WA. Available at www.nwfsc. noaa.gov/assets/25/6450_01302006_155445_NashFAOFinalTM71.pdf (accessed 27 Sept 2012)

NOAA (National Oceanic and Atmospheric Administration) (2011) National Oceanic and Atmospheric Administration marine aquaculture policy. US Dept of Commerce, NOAA, Seattle, WA. Available at www.nmfs.noaa.gov/ aquaculture/docs/policy/noaa_aquaculture_policy_2011. pdf (accessed 27 Sept 2011)

National Science and Technology Council Committee on Science Interagency Working Group on Aquaculture (2014) National strategic plan for federal aquaculture research (2014-2019). National Science and Technology Council, Washington, DC

> Navarro N, Leakey RJG, Black KD (2008) Effect of salmon cage aquaculture on the pelagic environment of temperate coastal waters: seasonal changes in nutrients and microbial community. Mar Ecol Prog Ser 361:47-58

> Neofitou N, Klaoudatos S (2008) Effect of fish farming on the water column nutrient concentration in a semi-enclosed gulf of the Eastern Mediterranean. Aquacult Res 39: 482-490

> Neori A, Chopin T, Troell M, Buschmann AH and others (2004) Integrated aquaculture: Rationale, evolution and state of the art emphasizing seaweed biofiltration in modern mariculture. Aquaculture 231:361-391

Nordvarg L, Håkanson L (2002) Predicting the environmental response of fish farming in coastal areas of the Åland Archipelago (Baltic Sea) using management models for coastal water planning. Aquaculture 206:217-243

> Nordvarg L, Johansson T (2002) The effects of fish farm effluents on the water quality in the Åland Archipelago, Baltic Sea. Aquacult Eng 25:253-279

Olsen L, Holmer M, Olsen Y (2008) Perspectives of nutrient emission from fish aquaculture in coastal waters: literature review with evaluated state of knowledge. Final report FHF project no. 542014. The Fishery and Aquaculture Industry Research Fund, Oslo

Page FH, Losier R, McCurdy P, Greenberg D, Chaffey J, Chang B (2005) Dissolved oxygen and salmon cage culture in the southwestern New Brunswick portion of the Bay of Fundy. In: Hargrave BT (ed) Environmental effects of marine finfish aquaculture. Handbook of environmental chemistry, Vol 5M. Springer-Verlag, Berlin, p 1-28

Pang SJ, Xiao T, Bao Y (2006) Dyanmic changes of total bacteria and Vibrio in an integrated seaweed-abalone culture system. Aquacult Fish Manag 252:289-297

- Parsons GJ, Shumway SE, Kuenstner S, Gryska A (2002) Polyculture of sea scallops (Placopecten magellanicus) suspended from salmon cages. Aquacult Int 10:65-77

Pearson TH, Black KD (2001) The environmental impacts of marine fish cage culture. In: Black KD (ed) Environmental impacts of aquaculture. CRC Press, Boca Raton, FL, p 1-31

> Pergent G, Mendez S, Pergent-Martini C, Pasqualini V (1999) Preliminary data on the impact of fish farming 
facilities on Posidonia oceanica meadows in the Mediterranean. Oceanol Acta 22:95-107

Philipose KK, Sharma SRK, Loka J, Damodaran D and others (2012) Observations on variations in physico-chemical water parameters of marine fish cage farm off Karwar. Indian J Fish 59:83-88

> Piedecausa MA, Aguado-Giménez F, Cerezo-Valverde J, Hernández-Llorente MD, García-García B (2010) Simulating the temporal pattern of waste production in farmed gilthead seabream (Sparus aurata), European seabass (Dicentrarchus labrax) and Atlantic bluefin tuna (Thunnus thynnus). Ecol Modell 221:634-640

Pitta P, Apostolaki ET, Giannoulaki M, Karakassis I (2005) Mesoscale changes in the water column in response to fish farming zones in three coastal areas in the Eastern Mediterranean Sea. Estuar Coast Shelf Sci 65:501-512

Pitta P, Tsapakis M, Apostolaki ET, Tsagaraki T, Holmer M, Karakassis I (2009) 'Ghost nutrients' from fish farms are transferred up the food web by phytoplankton grazers. Mar Ecol Prog Ser 374:1-6

Pittenger R, Anderson B, Benetti DD, Dayton P and others (2007) Sustainable marine aquaculture: fulfilling the promise; managing the risks. Marine Aquaculture Task Force, Takoma Park, MD

Prema D, Sobhana KS, Laxminarayana A, Imelda-Joseph Shoji-Joseph and others (2010) Observations on selected characteristics of water and sediment at the open sea cage culture site of Asian seabass Lates calcarifer (Bloch) off Cochin, south-west coast of India. Indian J Fish 57: 53-59

Redmond KJ, Magnesen T, Hansen PK, Strand Ø, Meier S (2010) Stable isotopes and fatty acids as tracers of the assimilation of salmon fish feed in blue mussels (Mytilus edulis). Aquaculture 298:202-210

Reid GK, Liutkus M, Robinson SMC, Chopin TR and others (2009) A review of the biophysical properties of salmonid faeces: implications for aquaculture waste dispersal models and integrated multi-trophic aquaculture. Aquacult Res 40:257-273

Reid GK, Liutkus M, Bennett A, Robinson SMC, MacDonald B, Page F (2010) Absorption efficiency of blue mussels (Mytilus edulis and M. trossulus) feeding on Atlantic salmon (Salmo salar) feed and fecal particulates: implications for integrated multi-trophic aquaculture. Aquaculture 299:165-169

Reid GK, Cranford PJ, Robinson SMC, Filgueira $R_{\text {, }}$ Guyondet T (2011) Open-water integrated multi-trophic aquaculture (IMTA): modelling the shellfish component. Bull Aquacult Assoc Canada 109:3-12

Rensel JE, Forster JRM (2007) Beneficial environmental effects of marine finfish mariculture. Final report, NOAA Award \# NA040AR4170130. US Dept of Commerce, NOAA, Washington, DC. Available at www.wfga.net/ documents/marine_finfish_finalreport.pdf (accessed 2 Oct 2012)

Rensel JEJ, Kiefer DA, Forster JRM, Woodruff DL, Evans NR (2007) Offshore finfish mariculture in the Strait of Juan de Fuca. Bull Fish Res Agency 19:113-129

> Rensel JEJ, Haigh N, Tynan TJ (2010) Fraser River sockeye salmon marine survival decline and harmful blooms of Heterosigma akashiwo. Harmful Algae 10:98-115

Ridler N, Wowchuk M, Robinson B, Barrington K and others (2007) Integrated multi-trophic aquaculture (IMTA): a potential strategic choice for farmers. Aquacult Econ Manag 11:99-110

Robinson SMC, Auffrey LM, Barbeau MA (2005) Far-field impacts of eutrophication on the intertidal zone in the
Bay of Fundy, Canada with emphasis on the soft-shell clam, Mya arenaria. In: Hargrave BT (ed) Environmental effects of marine finfish aquaculture. Handbook of environmental chemistry, Vol 5M. Springer-Verlag, Berlin, p 253-274

Robinson SMC, Martin JD, Cooper JA, Lander TR, Reid GK, Powell F, Griffin R (2011) The role of three dimensional habitats in the establishment of integrated multi-trophic aquculture (IMTA) systems. Bull Aquacult Assoc Canada 190:23-29

Ross LG, Telfer TC, Falconer L, Soto D, and others (2013a) Carrying capacities and site selection within the ecosystem approach to aquaculture. In: Ross LG, Telfer TC, Falconer L, Soto D, Aguilar-Manjarrez J (eds) Site selection and carrying capacities for inland and coastal aquaculture. FAO/Institute of Aquaculture, University of Stirling, Expert Workshop, 6-8 December 2010. FAO Fish Aquacult Proc 21. FAO, Rome, p 19-46

Ross LG, Telfer TC, Falconer L, Soto D, Aguilar-Manjarrez J (eds) (2013b) Site selection and carrying capacities for inland and coastal aquaculture. FAO/Institute of Aquaculture, University of Stirling, Expert Workshop, 6-8 December 2010. FAO Fish Aquacult Proc 21. FAO, Rome

Ruiz JM, Perez M, Romero J (2001) Effects of fish farm loadings on seagrass (Posidonia oceanica) distribution, growth and photosynthesis. Mar Pollut Bull 42:749-760

Rust MB, Barrows FT, Hardy RW, Lazur A, Naughten K, Silverstein J (2011) The future of aquafeeds. NOAA Tech Memo NMFS F/SPO-124. NOAA/USDA Alternative Feeds Initiative. Available at www.nmfs.noaa.gov/aquaculture/docs/feeds/the_future_of_aquafeeds_final.pdf (accessed 31 Oct 2012)

Sarà G (2007) Aquaculture effects on some physical and chemical properties of the water column: a meta-analysis. Chem Ecol 23:251-262

Sarà G, Zenone A, Tomasello A (2009) Growth of Mytilus galloprovincialis (Mollusca, Bivalvia) close to fish farms: a case of integrated multi-trophic aquaculture within the Tyrrhenian Sea. Hydrobiologia 636:129-136

Sarà G, Lo Martire M, Sanfilippo M, Pulicano G and others (2011) Impacts of marine aquaculture at large spatial scales: evidences from $\mathrm{N}$ and $\mathrm{P}$ catchment loading and phytoplankton biomass. Mar Environ Res 71:317-324

Sarà G, Reid GK, Rinaldi A, Palmeri V, Troell M, Kooijman SALM (2012) Growth and reproductive simulation of candidate shellfish species at fish cages in the Southern Mediterranean: dynamic energy budget (DEB) modelling for integrated multi-trophic aquaculture. Aquaculture 324-325:259-266

Schembri PJ, Baldacchino AE, Mallia A, Schembri T, Sant MJ, Stevens DT, Vella SJ (2002) Living resources, fisheries and agriculture. In: Axiak V, Gauci V, Mallia A, Mallia E, Schembri PJ, Vella AJ, Vella L (eds) State of the environment report for Malta, 2002. A report to the Ministry for Home Affairs and the Environment, Santa Venera, Malta, p 162-346. Available at www.mepa.org. $\mathrm{mt} / \mathrm{soer2002}$ (accessed 27 Sept 2012)

Silvert W (2001) Impact on habitats: determing what is acceptable. In: Tlusty MF, Bengston DA, Halvorson HO, Oktay SD, Pearce JB, Rheault RB (eds) Marine aquaculture and the environment: a meeting for stakeholders in the northeast. Cape Cod Printing, Falmouth, MA, p 16-40. Available at www.neaq.org/conservation_and_ research/projects/publications_and_presentations/pdf/12 _.pdf (accessed 2 Oct 2012)

Skaala Ø, Sjøtun K, Dahl E, Husa V, Bjørge A, Uiblein F 
(2014) Interactions between salmon farming and the ecosystem: lessons from the Hardangerfjord, western Norway. Mar Biol Res 10:199-202

Song XY, Huang LM, Zhang JL, Huang XP and others (2004) Variation of phytoplankton biomass and primary production in Daya Bay during spring and summer. Mar Pollut Bull 49:1036-1044

Soto D, Norambuena F (2004) Evaluation of salmon farming effects on marine systems in the inner seas of southern Chile: a large-scale mensurative experiment. J Appl Ichthyol 20:493-501

Sowles JW (2005) Assessing nitrogen carrying capacity for Blue Hill Bay, Maine: a management case history. In: Hargrave BT (ed) Environmental effects of marine finfish aquaculture. Handbook of environmental chemistry, Vol 5M. Springer-Verlag, Berlin, p 359-380

Srithongouthai S, Endo A, Inoue A, Kinoshita K and others (2006) Control of dissolved oxygen levels of water in net pens for fish farming by a microscopic bubble generating system. Fish Sci 72:485-493

Stickney RR (2002) Impacts of cage and net-pen culture on water quality and benthic communities. In: Tomasso JR (ed) Aquaculture and the environment in the United States. US Aquaculture Society, World Aquaculture Society, Baton Rouge, LA, p 105-118

Stirling HP, Okumus I (1995) Growth and production of mussels (Mytilus edulis L.) suspended at salmon cages and shellfish farms in two Scottish sea lochs. Aquaculture 134:193-210

Strain P, Hargrave B (2005) Salmon aquaculture, nutrient fluxes and ecosystem processes in southwestern New Brunswick. In: Hargrave BT (ed) Environmental effects of marine finfish aquaculture. Handbook of environmental chemistry, Vol 5M. Springer-Verlag, Berlin, p 29-57

Subasinghe RP, Arthur JR, Bartley DM, De Silva SS and others (2012) Farming the waters for people and food. Proc Glob Conf Aquacult, Phuket, Thailand, 22-25 September 2010. FAO, Rome and NACA, Bangkok. Available at www.fao.org/docrep/015/i2734e/i2734e.pdf (accessed on 15 Jan 2012)

Sun CC, Wang YS, Wu ML, Dong JD, Wang YT, Sun FL, Zhang YY (2011) Seasonal variation of water quality and phytoplankton response patterns in Daya Bay, China. Int J Environ Res Public Health 8:2951-2966

Tanaka K, Kodama M (2007) Effects of resuspended sediments on the environmental changes in the inner part of Ariake Bay, Japan. Bull Fish Res Agency 19:9-15

Tett P (2008) Fish farm waste in the ecosystem. In: Holmer M, Black K, Duarte CM, Marba N, Karakassis I (eds) Aquaculture in the ecosystem. Springer, Dordrecht, p 1-46

Tett P, Portilla E, Gillibrand PA, Inall M (2011) Carrying and assimilative capacities: the ACExR-LESV model for sealoch aquaculture. Aquacult Res 42:51-67

Tlusty MF, Pepper VA, Anderson MR (2005) Reconciling aquaculture's influence on the water column and benthos of an estuarine fjord-a case study from Bay d'Espoir, Newfoundland. In: Hargrave BT (ed) Environmental effects of marine finfish aquaculture. Handbook of environmental chemistry, Vol 5M. Springer-Verlag, Berlin, p 115-128

Troell M, Joyce A, Chopin T, Neori A, Buschmann AH, Fang JG (2009) Ecological engineering in aquaculture: potential for integrated multi-trophic aquaculture (IMTA) in marine offshore systems. Aquaculture 297:1-9

Trushenski JT, Kasper CS, Kohler CC (2006) Challenges and opportunities in finfish nutrition. N Am J Aquacult 68: $122-140$
Tsagaraki TM, Petihakis G, Tsiaras K, Triantafyllou G and others (2011) Beyond the cage: ecosystem modelling for impact evaluation in aquaculture. Ecol Modell 222: 2512-2523

Tsagaraki TM, Pitta P, Frangoulis C, Petihakis G, Karakassis I (2013) Plankton response to nutrient enrichment is maximized at intermediate distances from fish farms. Mar Ecol Prog Ser 493:31-42

Tucker CS, Hargreaves JA (eds) (2008) Environmental best management practices for aquaculture. Wiley-Blackwell, Ames, IA

Vargas-Machuca SC, Ponce-Palafox JT, Arredondo-Figueroa JL, Chávez-Ortiz EA, Vernon-Carter EJ (2008) La variación de los parametros fisico-químicos del agua en jaulas flotantes de pargos (Lutjanus peru y L. guttatus) en una granja marina tropical. Physico-chemical water parameters variation in the floating cages of snappers (Lutjanus peru and L. guttatus) farmed in tropical sea. Rev Mex Ing Quim 7:237-242

- Vargo GA (2009) A brief summary of the physiology and ecology of Karenia brevis Davis (G. Hansen and Moestrup comb. nov.) red tides on the West Florida Shelf and of hypotheses posed for their initiation, growth, maintenance, and termination. Harmful Algae 8:573-584

> Vezzulli L, Moreno M, Marin V, Pezzati E, Bartoli M, Fabiano M (2008) Organic waste impact of capture-based Atlantic bluefin tuna aquaculture at an exposed site in the Mediterranean Sea. Estuar Coast Shelf Sci 78:369-384

> Vizzini S, Mazzola A (2006) The effects of anthropogenic organic matter inputs on stable carbon and nitrogen isotopes in organisms from different trophic levels in a southern Mediterranean coastal area. Sci Total Environ 368:723-731

- Vizzini S, Savona B, Caruso M, Savona A, Mazzola A (2005) Analysis of stable carbon and nitrogen isotopes as a tool for assessing the environmental impact of aquaculture: a case study from the western Mediterranean. Aquacult Int 13:157-165

Wang X, Olsen LM, Reitan KI, Olsen Y (2012) Discharge of nutrient wastes from salmon farms: environmental effects, and potential for integrated multi-trophic aquaculture. Aquacult Environ Interact 2:267-283

> Whitmarsh DJ, Cook EJ, Black KD (2006) Searching for sustainability in aquaculture: an investigation into the economic prospects for an integrated salmon-mussel production system. Mar Policy 30:293-298

Wildish DJ, Dowd M, Sutherland TF, Levings CD (2004) Near-field organic enrichment from marine finfish aquaculture. Can Tech Rep Fish Aquat Sci 2450, Vol 3. DFO, Ottawa. Available at www.dfo-mpo.gc.ca/Library/285141. pdf (accessed 11 Sept 2013)

> Wu RSS (1995) The environmental impact of marine fish culture: towards a sustainable future. Mar Pollut Bull 31: 159-166

Yabanh M, Egemen Ö (2009) Monitoring the environmental impacts of marine aquaculture activities on the water column and sediment in vicinity of the Karaburun Peninsula (Turkey-Eastern Aegean Sea). J FisheriesSciences. com 3:207-213

> Yu J, Tang DL, Oh IS, Yao LJ (2007) Response of harmful algal blooms to environmental changes in Daya Bay, China. Terr Atmos Ocean Sci 18:1011-1027

Yucel-Gier G, Pazi I, Kucuksezgin F, Kocak F (2011) The composite trophic status index (TRIX) as a potential tool for the regulation of Turkish marine aquaculture as applied to the eastern Aegean coast (Izmir Bay). J Appl Ichthyol 27:39-5 